\title{
Polar cap convection/precipitation states during Earth passage of two ICMEs at solar minimum
}

\author{
P. E. Sandholt ${ }^{1}$, Y. Andalsvik ${ }^{1}$, and C. J. Farrugia ${ }^{2}$ \\ ${ }^{1}$ Department of Physics, University of Oslo, Oslo, Norway \\ ${ }^{2}$ Space Science Center, University of New Hampshire, Durham, USA
}

Received: 30 September 2009 - Revised: 26 March 2010 - Accepted: 22 April 2010 - Published: 30 April 2010

\begin{abstract}
We report important new aspects of polar cap convection and precipitation (dawn-dusk and inter-hemisphere asymmetries) associated with the different levels of forcing of the magnetosphere by two interplanetary (IP) magnetic clouds on 20 November 2007 and 17 December 2008 during solar minimum. Focus is placed on two intervals of southward magnetic cloud field with large negative $B_{\mathrm{y}}$ components $\left(B_{\mathrm{x}}=-5\right.$ versus $\left.0 \mathrm{nT}\right)$ and with high and low plasma densities, respectively, as detected by spacecraft Wind. The convection/precipitation states are documented by DMSP spacecraft (Southern Hemisphere) and SuperDARN radars (Northern Hemisphere). The (negative) $B_{\mathrm{y}}$ component of the cloud field is accompanied by a newly-discovered flow channel (called here FC 2) threaded by old open field lines (in polar rain precipitation) at the dusk and dawn sides of the polar cap in the Northern and Southern Hemispheres, respectively, and a corresponding Svalgaard-Mansurov (SM) effect in ground magnetic deflections. On 20 November 2007 the latter S-M effect in the Northern winter Hemisphere appears in the form of a sequence of six 5-10 min long magnetic deflection events in the 71-74 ${ }^{\circ}$ MLAT/14:30 16:00 MLT sector. The X-deflections are consistent with the flow direction in FC 2 (i.e. caused by Hall currents) in both IP cloud cases. The presence of a lobe cell and associated polar arcs in the Southern (summer) Hemisphere in the low density $\left(1-2 \mathrm{~cm}^{-3}\right)$ and $B_{\mathrm{x}}=0$ ICME case is accompanied by the dropout of polar rain precipitation in the dusk-side regime of sunward polar cap convection and inward-directed Birkeland current. The low-altitude observations are discussed in terms of momentum transfer via dynamo processes in the high- and low-latitude boundary layers and Birkeland currents located poleward of the traditional R1-R2 system.
\end{abstract}

Keywords. Ionosphere (Plasma convection) - Magnetospheric physics (Current systems; Polar cap phenomena)

Correspondence to: P. E. Sandholt (p.e.sandholt@fys.uio.no)

\section{Introduction}

We present a study of certain aspects of the spatial and temporal structure of the reconnecting magnetosphere associated with dawn-dusk and inter-hemisphere asymmetries in polar cap convection and precipitation. This fine-structure in the convection/precipitation states is considered to be essential for an adequate understanding of solar wind-magnetosphere coupling. It includes the temporal evolution of plasma convection, involving stages of newly-open (LLBL/cusp precipitations) and old-open (mantle/polar rain precipitations) magnetic field lines, as well as spatial convection structure, i.e., the issue of cell structure (merging and lobe cells) in the Northern and Southern Hemispheres. A third, related aspect is the question of inter-hemisphere symmetry/asymmetry in polar cap precipitation including polar rain and polar cap arcs. It is our opinion that an approach through case studies is the most appropriate one for resolving these convection/precipitation features.

In recent investigations we argued that it is reasonable to distinguish between different types of plasma flow channels corresponding to two different stages of the evolution of field lines opened by dayside reconnection; i.e., newly open and old open field lines, respectively (Farrugia et al., 2003; Sandholt et al., 2004; Farrugia et al., 2004; Lund et al., 2008; Sandholt and Farrugia, 2009). Each of the two stages drives a characteristic flow channel, called hereunder FC 1 and FC 2. Our effort has been to establish the importance of FC 2 as a signature of efficient momentum transfer on old open field lines and its different source compared to FC 1 , namely, through its coupling to the solar wind dynamo in the high-latitude boundary layer (HBL). We demonstrated that flow channel FC 2, which typically consists of a $200-300 \mathrm{~km}$ wide band of enhanced $(1-3 \mathrm{~km} / \mathrm{s})$ antisunward convection situated at the dusk- or dawn-side polar cap boundary, enhances and extends the IMF $B_{\mathrm{y}}$-related dawn-dusk asymmetry of polar cap convection. In Sandholt and Farrugia (2009) we distinguished between four categories of the flow channel

Published by Copernicus Publications on behalf of the European Geosciences Union. 


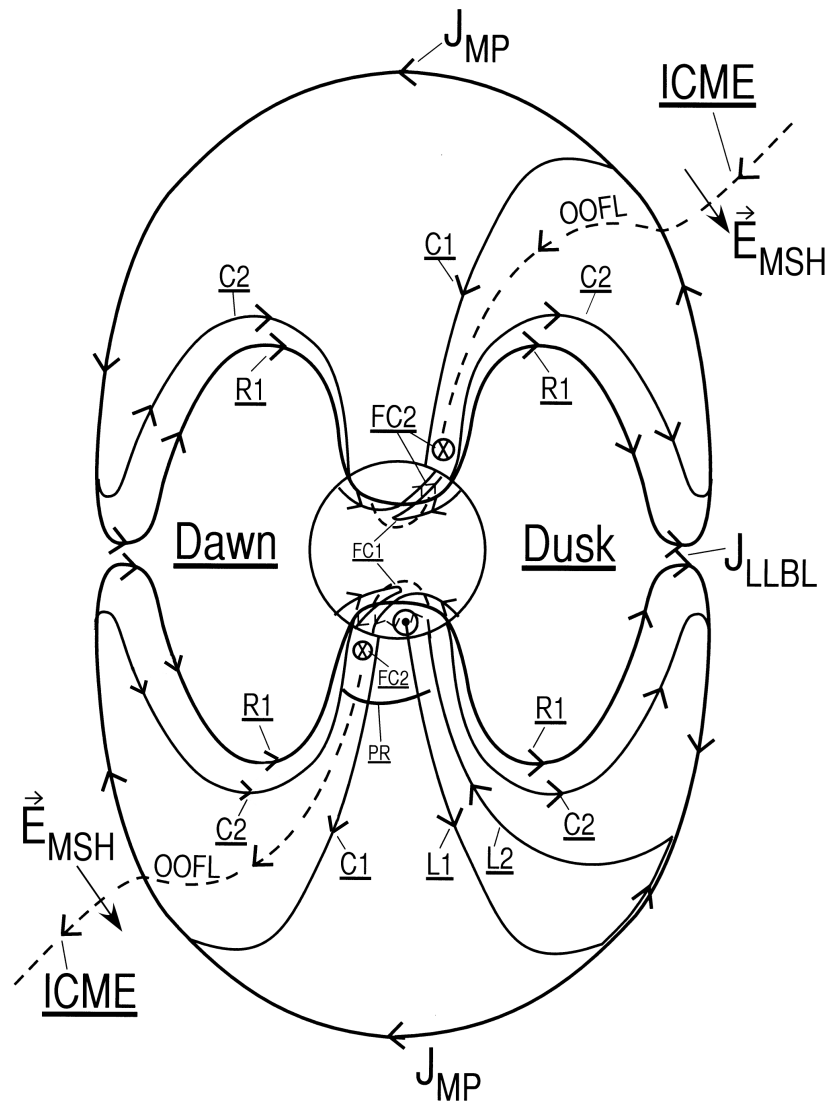

Fig. 1. A schematic illustration of the ICME-magnetosphere interconnection topology for $B_{\mathrm{y}}<0$ conditions and Birkeland currents current systems in the Northern $(\mathrm{NH})$ and Southern $(\mathrm{SH})$ Hemispheres relating to flow channels FC $2(\boldsymbol{E} \times \boldsymbol{B}$ - drift $)$ in the north $\left(\mathrm{NH}-\right.$ dusk $\left./ B_{\mathrm{y}}<0\right)$ and south $\left(\mathrm{SH}-\right.$ dawn $\left./ B_{\mathrm{y}}<0\right)$. The perspective is looking from the Sun towards the Earth. (North is up and Dusk is to the right). The poleward and equatorward branches of the R1 Birkeland current, connected to the outer and inner edges of the low-latitude boundary layer (LLBL), are marked C2 and R1, respectively. These Birkeland currents are connected to the magnetopause current $\left(J_{\mathrm{MP}}\right)$ at high latitudes via $J_{\mathrm{LLBL}}$ in the LLBL and to the Pedersen current $\left(J_{\mathrm{P}}\right)$ at the ionospheric level. The $\mathrm{C} 1$ Birkeland current is threaded by old open field lines (OOFL) and polar rain (PR) precipitation. Plasma flows in dawn-dusk asymmetric convection cells applicable to our cases are indicated: 2-cell pattern in north and 3-cells in the south. The lobe cell in the Southern Hemisphere (marked by circle) is favoured by the summer dipole tilt. The associated Birkeland currents are marked L1-L2. Current L1 is associated with polar arcs while current L2 is accompanied by a dropout of polar rain precipitation. The $\boldsymbol{E}$-field/momentum coupling from the magnetosheath $\left(\boldsymbol{E}_{\mathrm{MSH}}\right)$ to the ionosphere (FC 2) along old open field lines is indicated. Flow channels FC 1 on newly open field lines (Cusp/LLBL precipitation) are also marked.

FC 2 depending on the relevant combinations of IMF $B_{\mathrm{y}}$ polarity, hemisphere (N/S), and dawn/dusk side of the polar cap. In this study we explore the FC 2 variants in both hemispheres under IMF $B_{\mathrm{y}}<0$ conditions (NH-dusk $/ B_{\mathrm{y}}<0$ and
SH-dawn $/ B_{\mathrm{y}}<0$ ) further and place them in the context of polar cap convection/precipitaton states as detected by DMSP spacecraft and SuperDARN radars.

In previous studies we have repeatedly pointed out that flow channel FC 2 may give rise to a component of the Svalgaard-Mansurov effect Svalgaard (1973) that comes in addition to (spatial extension in the antisunward direction) the ground magnetic deflection which is attributed to the effect of magnetic tension on newly open magnetic field lines. In our terminology the latter is the FC 1 - related ground deflection in the cusp/cleft region. In this study we report a detailed documentation of the ground magnetic deflection (Svalgaard-Mansurov effect) associated with channel FC 2 appearing in the NH-dusk/ $B_{\mathrm{y}}<0$ variant during the Earth passage of the 20 November 2007 interplanetary (IP) magnetic cloud (MC). The temporal behaviour of flow channel FC 2 may be derived from the associated ground magnetic deflections.

The spatial structure we study involves the interhemisphere asymmetry of lobe cell convection (Crooker and Rich, 1993), associated polar arcs (Eriksson et al., 2003) and dropout of polar rain precipitation at dusk in the Southern Hemisphere (adjacent to the polar arcs) under the prevailing external magnetic field (southwest: $B_{\mathrm{Z}}<0 ; B_{\mathrm{y}}<0 ; B_{\mathrm{x}}=0$ ) and the low $\left(<1 \mathrm{~cm}^{-3}\right)$ plasma density conditions in one MC.

We selected two intervals of $B_{\mathrm{y}}$-negative forcing by IP magnetic clouds (Burlaga et al., 1981) passing Earth during the minimum phase of solar cycle 24 . These two cloud intervals correspond to high $\left(10-20 \mathrm{~cm}^{-3}\right)$ and low $\left(1-2 \mathrm{~cm}^{-3}\right)$ plasma densities, respectively. The levels of solar wind forcing and IMF $B_{\mathrm{X}}$ conditions (zero versus $-5 \mathrm{nT}$ ) were also different. This allows us to explore the influence of solar wind forcing, plasma density and IMF $B_{\mathrm{X}}$ on the polar cap convection and precipitation states. The abrupt polar rain dropout mentioned above is different from the "normal" IMF $B_{\mathrm{y}}$ dependent dawn-dusk asymmetry (smooth gradient) of polar rain precipitation (Meng et al., 1977). The different flow speeds corresponding to the FC 2 flow channels in the two cloud cases are tentatively attributed to the different levels of forcing as estimated by the Boyle et al. (1997) formula for the cross-polar cap potential (CPCP).

This paper is organised as follows. First we describe the model of solar wind-magnetosphere-ionosphere coupling which provides a conceptual framework for interpreting the observations. In the data description section we report the observations in the two case examples. This is followed by a summary of the observations and their discussion in terms of the conceptual model of ICME-magnetosphere-ionosphere coupling.

\section{Model description}

Figure 1 shows a schematic illustration of our conceptual model of solar wind-magnetosphere-ionosphere coupling 
applicable to the conditions of the southwest-directed magnetic fields in the two ICMEs that we present in this study. The model consists of the following elements:

1. The R1 Birkeland current is split into two branches (R1 and C2) corresponding to two branches of ionospheric Pedersen current closure, the auroral zone branch and the polar cap branch (not shown). R1 is connected to field-transverse current ( $J_{\text {LLBL }}$ ) at the LLBL inner edge (closed bloundary layer) while $\mathrm{C} 2$ is connected to the LLBL outer (open boundary layer) part ( $\left.J_{\text {LLBL }}\right)$. For a discussion of this type of IMF-magnetosphere interconnection topology, LLBL substructure (and flow shear) and associated Birkeland current excitation we refer to the MHD simulations of Siscoe and Siebert (2003) (see their Fig. 3) and the boundary layer theory of Sonnerup and Siebert (2003).

2. Flow channel FC 2, threaded by "old open field lines" (OOFL) and polar rain precipitation (Fairfield and Scudder, 1985; Sotirelis et al., 1997), is observed on the opposite sides (dawn/dusk) in the two hemispheres for the prevailing negative polarity of the magnetic field $B_{\mathrm{y}}$ component in the ICME (NH-dusk/ $B_{\mathrm{y}}<0$ and $\mathrm{SH}$ dawn $\left./ B_{\mathrm{y}}<0\right)$. Areas of "newly open field lines" and flow channel FC 1 in the cusp region are also marked (inside dashed curved line). The latter indicates the projected dayside merging (reconnection) line.

3. As we shall document in this paper momentum transfer via the $\mathrm{C} 1-\mathrm{C} 2$ currents give rise to flow channel FC 2 (see also Sandholt and Farrugia, 2009) and its associated Hall currents gives the antisunward extension of the Svalgaard-Mansurov effect beyond the cusp/cleft region. The latter effect comes in addition to the flowasymmetry which is due to magnetic tension on newly open field lines.

4. A lobe cell with polar arcs in its center is present in the hemisphere (south) where dipole tilt (summer) is favourable for lobe reconnection (Crooker and Rich, 1993).

5. The Birkeland currents marked L1-L2 are those which are associated with lobe cell convection (Eriksson et al., 2002).

6. The outward-directed Birkeland current (L1) in the center of the lobe cell is accompanied by flow shear arcs (Reiff et al., 1978). These polar cap arcs are accelerated polar rain precipitation in the region of a converging electric field (see Carlson and Cowley, 2005; Sandholt et al., 2006).

7. The inward-directed Birkeland current (L2) in the duskside part of the lobe cell is located equatorward of the regime of sunward convection. As we shall see below this region is characterized by the dropout of polar rain precipitation. The presence of polar rain (PR) in the dawn side of the polar cap in the Southern Hemisphere is marked in the figure. As mentioned earlier, the polar rain dropout discussed here in connection with a proposed downward/inward FAC is different from the normal dawn-dusk polar rain asymmetry (smooth gradient) and its IMF $B_{\mathrm{y}}$-dependence (Newell et al., 2009).

The ICME-magnetosphere interconnection topology indicated in Fig. 1 implies that flow channel FC 2 is part of the low-altitude mapping of the Stern gap (Stern, 1984). FC 2 appears as a result of effective $\boldsymbol{E}$-field/momentum coupling from the magnetosheath $\left(\boldsymbol{E}_{\mathrm{MSH}}\right)$ along old-open field lines. As we shall see in the cases reported below an interhemispheric asymmetry in FC 2 excitation seems to be related to the background conductivity (sunlight conditions). There are also indications that the degree of solar wind forcing is a factor for the strength of the FC 2 flow. As regards the conductivity effect we find that our result is consistent with previous studies of solar wind-magnetosphere coupling indicating that the solar wind acts like a current-limited voltage generator (see e.g. Borovsky et al., 2009).

\section{Data description}

\subsection{Case 1: 17 December 2008}

Figure 2 shows Wind plasma and magnetic field data from the SWE (Ogilvie et al., 1995) and the MFI (Lepping et al., 1995) instruments, respectively. Wind was located at $(254,-28,24) R_{\mathrm{E}}$ at the center of the interval of interest (10:00 UT, 17 December). From top to bottom the panels show the proton plasma density, bulk speed, and temperature, the dynamic pressure, the magnetic field strength and the magnetic field components in GSM coordinates, the proton plasma beta and, in red, the Alfvén Mach number, and the IMF clock angle, i.e., the polar angle in the GSM (YZ) plane. The bottom panel shows the cross polar cap potential (CPCP) after Boyle et al. (1997). The latter is used as an expression for the level of solar wind forcing.

The period of low density (average $\sim 1.9 \pm 1.0 \mathrm{~cm}^{-3}$ ), and correspondingly low dynamic pressure (average $0.36 \pm 0.18 \mathrm{nPa}$ ) during the time interval $03.30-13.40 \mathrm{UT}$ stands out. During this time the field executes a large and smooth rotation. This was identified by Davis et al. (2009) as the "void" region of an ICME corresponding to the dark cavity of the CME. It is a slow moving configuration, where a wide range of clock angles are realized and, with its strongly westward - pointing field $\left(B_{\mathrm{y}}<0\right)$, there is a an interval of several hours where the field's clock angle stays close to $90^{\circ}$.

We shall confine our analysis of magnetospheric/ionospheric data to the interval 11:00-15:00 UT, 


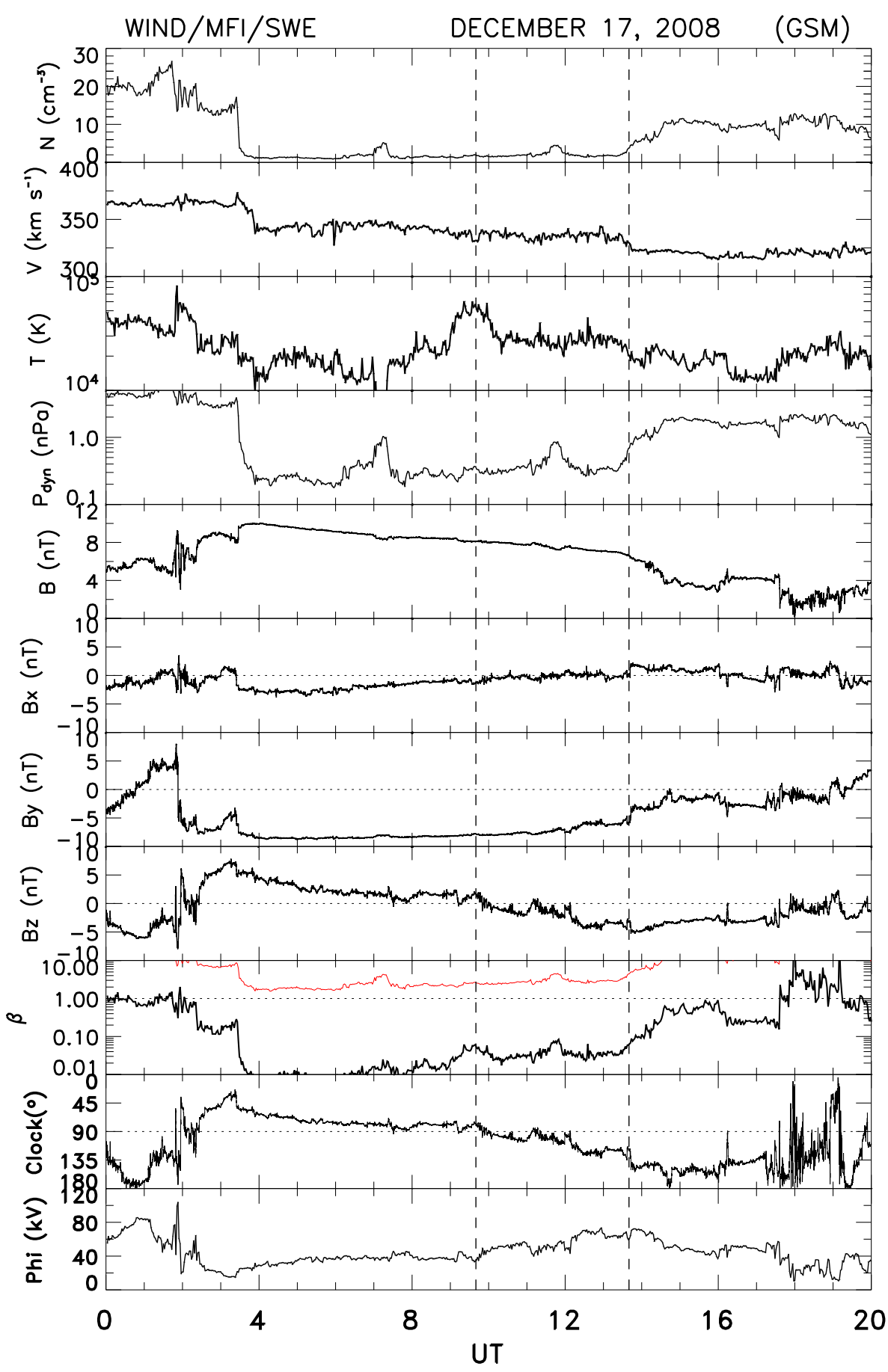

Fig. 2. Wind plot for the interval 00:00-20:00 UT, 17 December 2008. From top to bottom the panels show the proton plasma density, bulk speed, and temperature, the dynamic pressure, the magnetic field strength and the magnetic field components in GSM coordinates, the proton plasma beta and, in red, the Alfvén mach number, and the IMF clock angle, i.e., the polar angle in the GSM (YZ) plane. The interval corresponding to the low-altitude observations discussed in this paper is marked by vertical guidelines.

placed at the rear end of the ICME. With an estimate convection delay of $\sim 80 \mathrm{~min}$, this corresponds to interplanetary conditions shown between the vertical guidelines. In this interval the ICME field goes from being $B_{\mathrm{y}}$-dominated (clock angle $=90^{\circ}$ ) to more $B_{\mathrm{Z}}$-dominated (clock angle $=140^{\circ}$ ). The density is $2 \mathrm{~cm}^{-3}$ except for the rise at the end of the interval (13:30-14:30 UT). 


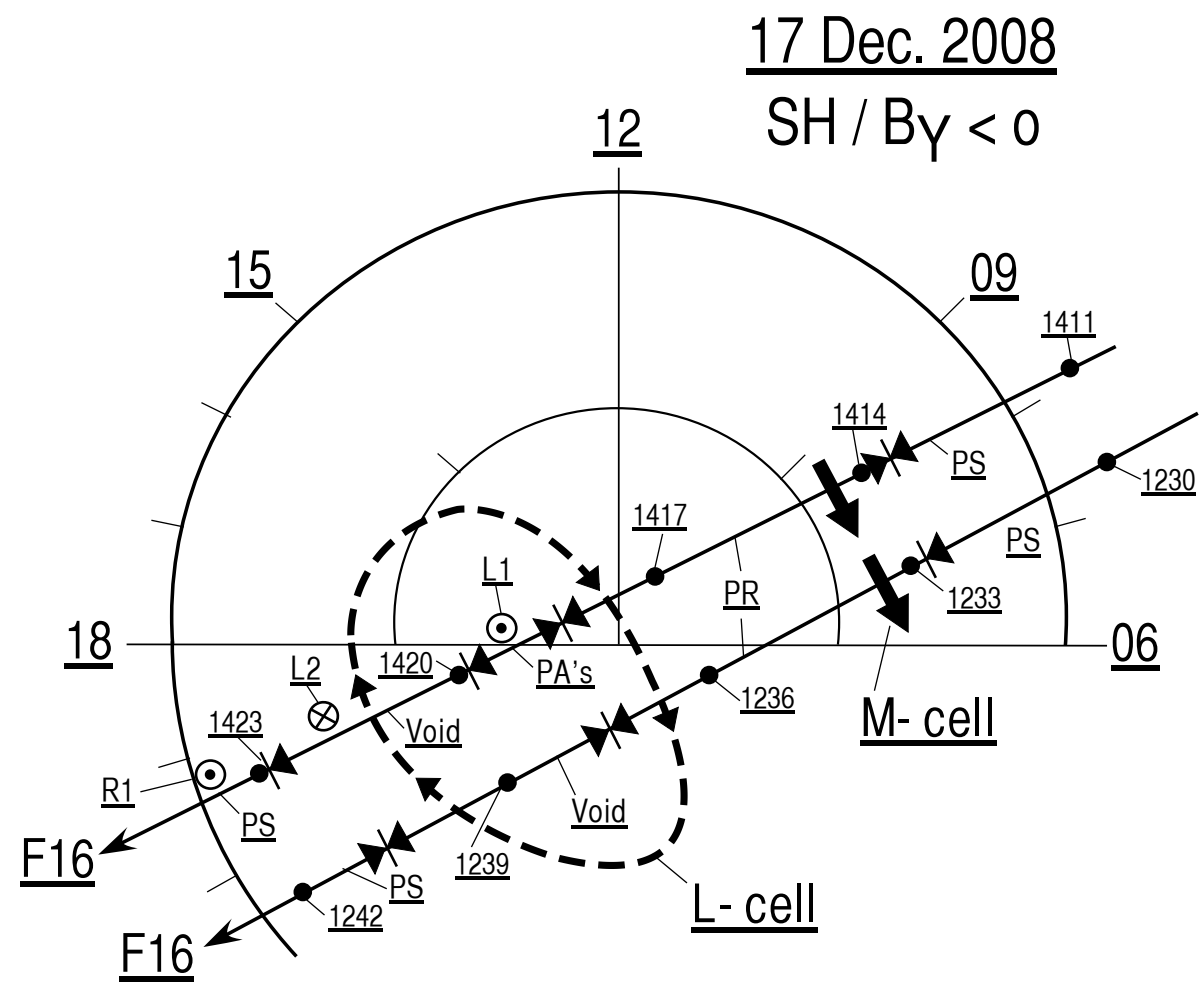

Fig. 3. Tracks of spacecraft DMSP F16 during the intervals 12:30-12:42 and 14:11-14:23 UT plotted in MLT/MLAT coordinates. Precipitation (PS; PR; PAs; void) and Birkeland current (L1; L2; R1) regimes along the tracks are indicated. Cross-track ion drifts in the merging (antisunward; dawn side) and lobe (sunward; dusk side) convection cells are also marked. A lobe cell circulation which is consistent with the satellite observations has been schematically indicated by the dashed loop.

Figure 3 shows tracks of spacecraft DMSP F16 during the intervals 12:30-12:42 and 14:11-14:23 UT. Precipitation regimes such as PS (plasma sheet), PR (polar rain), PAs (polar arcs), void and Birkeland current regimes (L1; L2; R1) along the tracks are indicated. Cross - track ion drifts in the merging (antisunward; dawn side) and lobe (sunward; dusk side) cells are also marked. A lobe cell circulation which is consistent with the satellite observations has been schematically indicated by the dashed loop. Thus the present convection configuration is the composite pattern consisting of merging and convection cells which has been predicted and simulated during intervals of $B_{\mathrm{y}}$-dominated IMF orientations (Reiff and Burch, 1985; Crooker et al., 1998). The associated polar arcs in the lobe cell during intervals of similar IMF conditions has been documented in previous studies (Eriksson et al., 2003; Sandholt et al., 2006). For information on the L1-L2 Birkeland currents we refer to Eriksson et al. (2002).

Flow shear (gradient in cross-track ion drift) is observed in sector of polar arcs (PAs). This means that the PAs are socalled flow shear arcs (Reiff et al., 1978). Polar arcs are located where the flow shear is largest in the lobe cell. Sunward flow in the polar cap is defined as lobe cell convection. This convection feature is driven by lobe reconnection (Crooker and Rich, 1993). The "void" region marks the dropout of polar rain precipitation in the lobe cell on the dusk side of the polar arcs. This abrupt dropout is an effect which is different from the smooth dawn-dusk gradient of polar rain associated with IMF $B_{\mathrm{y}}$. The corresponding data are shown below.

Figure 4 shows DMSP F16 data during a polar cap crossing from the dawn (07:00 MLT; $-77^{\circ}$ MLAT) to the evening (21:00 MLT; $-73^{\circ}$ MLAT) side in the Southern Hemisphere. Different convection/precipitation states are marked by vertical guidelines. We note the following features of electron precipitation (top panel) and cross-track ion drift (fourth panel):

(i) antisunward convection and polar rain (PR) precipitation on the dawn side (left) of the central polar cap, (ii) sunward convection and dropout of polar rain precipitation on the evening side of the polar cap (between the second and third vertical guidelines).

Figure 5 shows DMSP F16 data during a subsequent crossing of the polar cap from the morning (8.3 MLT; $-77.2^{\circ}$ MLAT; 14:14 UT) to the evening (19.3 MLT; $-73.1^{\circ}$ MLAT) side. We shall focus attention on the following features:

(i) polar rain (PR) precipitation and antisunward convection on the morning side of the polar cap, (ii) traversal of a regime 


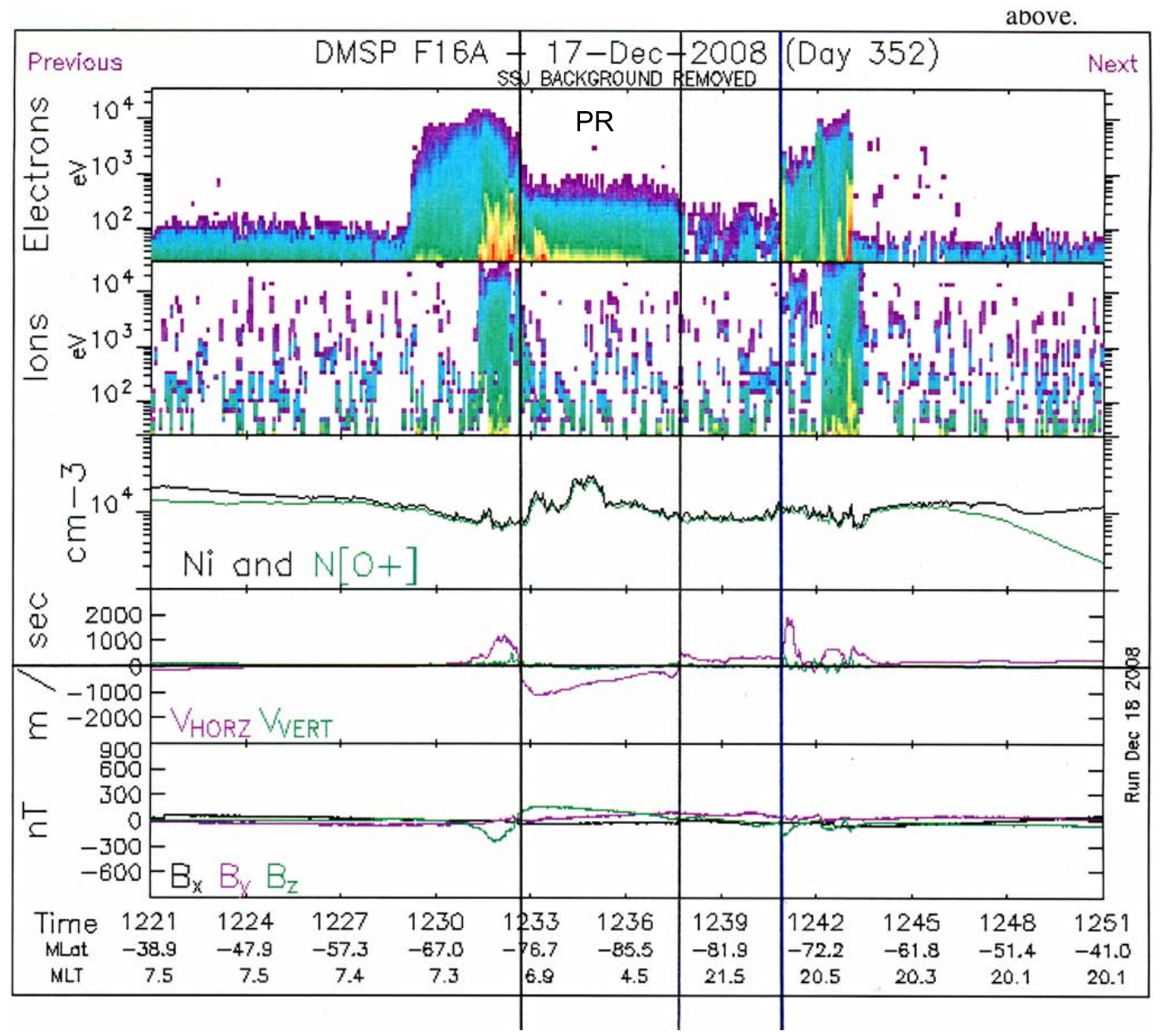

Fig. 4. DMSP F16 Southern Hemisphere data for the interval 12:21-12:51 UT on 17 December 2008. Panels from top to bottom show electron precipitation flux, ion precipitation flux, ion densities, cross track ion drifts, and magnetic deflection components $B_{\mathrm{X}}, B_{\mathrm{y}}$, and $B_{\mathrm{Z}}$. Polar rain (PR), polar arcs (PA) and dropout of polar rain on the dusk side of the arcs have been marked. Different convection/precipitation states are marked by vertical guidelines. Dropout of polar rain in the regime of sunward convection is marked by the second and third vertical guidelines.

of higher energy electrons (polar arc; PA) on the dusk side of the polar cap, (iii) dropout of polar rain precipitation in the regime of sunward convection in the evening sector of the polar cap (between the fourth and the fifth vertical guidelines).

Figure 6 shows tracks of spacecraft DMSP F13 and F17 across the polar cap from dawn to dusk in the Southern Hemisphere (SH) during the interval 13:20-13:30 UT. These F13 and F17 passes occurred between the two previously described F16 passes (Figs. 3-5). Particle precipitation and Birkeland current regimes along the tracks are marked. Flow channel FC $2\left(\mathrm{SH}-\right.$ dawn $\left./ B_{\mathrm{y}}<0\right)$, as detected by spacecraft DMSP F17, is indicated by the hatched arrow. This flow channel appears slightly weaker in the F13 data in Fig. 8 (peak velocity $1.2 \mathrm{~km} / \mathrm{s}$ versus $1.5 \mathrm{~km} / \mathrm{s}$ ).

The sector called "void" marks the dropout of polar rain in the regime of sunward convection (lobe cell) on the dusk side of the polar arcs (PAs) in the F13 data. The Birkeland current regimes L1 (outward in PA regime) and L2 (inward in "void" regime) are those which are also marked in Fig. 1. The corresponding data sets are shown below.

Figure 7 shows DMSP F13 data during a crossing of the polar cap in the Southern Hemisphere from the dawn (7.5 MLT; $\sim-78.3^{\circ}$ MLAT) to the dusk (17.4 MLT; $80.4^{\circ}$ MLAT) side during the interval 13:21-13:28 UT. We note the following features:

(i) dawn-dusk asymmetric antisunward convection (fourth panel) and polar rain (PR) electron precipitation (top panel) in the central polar cap, (ii) the presence of polar arcs (PAs) on the dusk side of the polar cap at high latitudes $(\sim 82-$ $85^{\circ}$ MLAT), (iii) sunward convection and dropout of polar rain precipitation between the polar cap arcs and auroral oval (between the second and third guidelines) on the dusk side.

Figure 8 shows DMSP F17 data for a dawn-dusk polar cap crossing in the Southern Hemisphere during the interval 


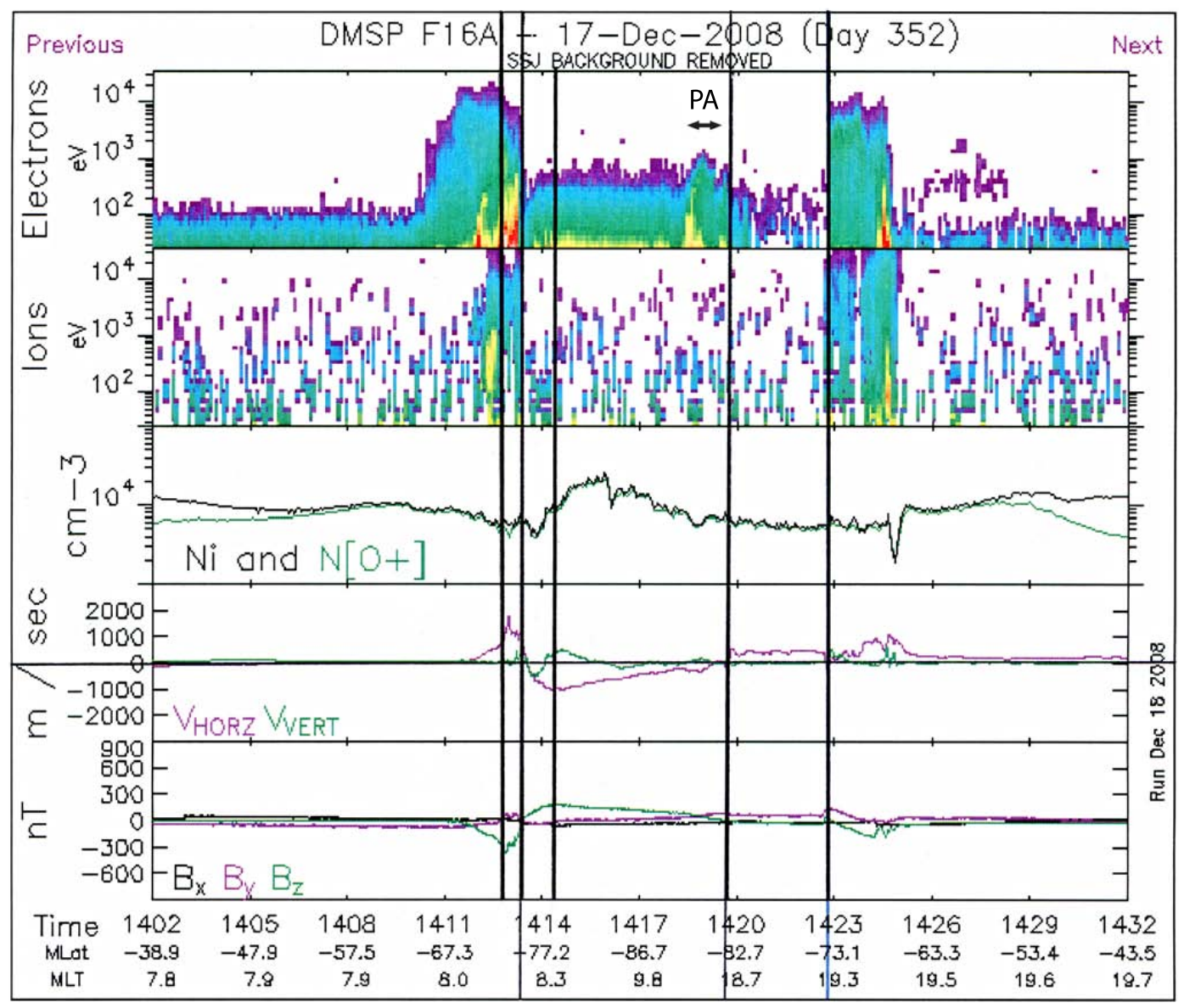

Fig. 5. DMSP F16 data representing the interval 14:02-14:32 UT on 17 December 2008. Particle precipitation, ion drift, and magnetic deflections obtained by spacecraft DMSP F 13 during a Southern Hemisphere pass during 13:10-13:40 UT on 17 December 2008. Same format as in Fig. 4.

13:10-13:40 UT. We note that this is identical to the F13 interval shown in Fig. 7. We shall focus on the interval 13:2113:28 UT when the spacecraft crossed into the polar cap on the dawn side ( $\sim$ 07:00 MLT; $78^{\circ}$ MLAT) and exited the polar cap on the dusk side ( 16:00 MLT; $80^{\circ}$ MLAT). We notice the following features: (i) asymmetric cross-track (antisunward) ion drift with continuously decreasing speeds in the central polar cap (polar rain/PR precipitation) from the dawn to the dusk side. (ii) The dusk side of the polar cap (between vertical guidelines) is characterized by a large flow shear centered on the convection reversal and associated inverted-V type electron precipitation (polar arcs; PAs). (iii) A channel of enhanced $(1.5 \mathrm{~km} / \mathrm{s})$ antisunward convection near the auroral precipitation boundary on the dawn (left) side of the polar cap. This is our flow channel FC 2. There are slightly different FC 2 signatures in the DMSP observations obtained in the close passes made by DMSP F13 (Fig. 7: $77^{\circ}$ MLAT/7.3 MLT) and F17 (Fig. 8: $78^{\circ}$ MLAT/7.0 MLT) at 13:21 UT. The FC 2 signature is marginally stronger in the F17 data (maximum speed $1.5 \mathrm{~km} / \mathrm{s}$ ) compared to the F13 data (maximum speed $1.2 \mathrm{~km} / \mathrm{s}$ ). This is an indication of spatial structure in the FC 2 flow channel.

Figure 9 shows a spatial plot of plasma convection in the postnoon sector for the scan at 11:12-11:14 UT on 17 December 2008 obtained by SuperDARN radars in Finland and Iceland (http://superdarn.jhuapl.edu) (Greenwald et al., 1995; Ruohoniemi and Greenwald, 2005). Dawn is to the right. We notice the presence of a rotational convection reversal in the postnoon sector with a channel of enhanced (yellow) antisunward flow on its poleward side. The latter, which we identify as our flow channel FC 2 (category NH$\left.\operatorname{dusk} / B_{\mathrm{y}}<0\right)$, is centered at $80^{\circ}$ MLAT/15:00-18:00 MLT. We emphasize that these data are from the Northern Hemisphere and that the FC 2 flow channel is observed in a sector of dark ionosphere. Thus, the level of background ionization is low in this winter case.

Figure 10 shows the convection configuration in the postnoon/dusk sector obtained by SuperDARN radars at 14:0014:02 UT. Dashed line marks the position of the discrete aurora, as observed by meridian scanning photometer (MSP) 


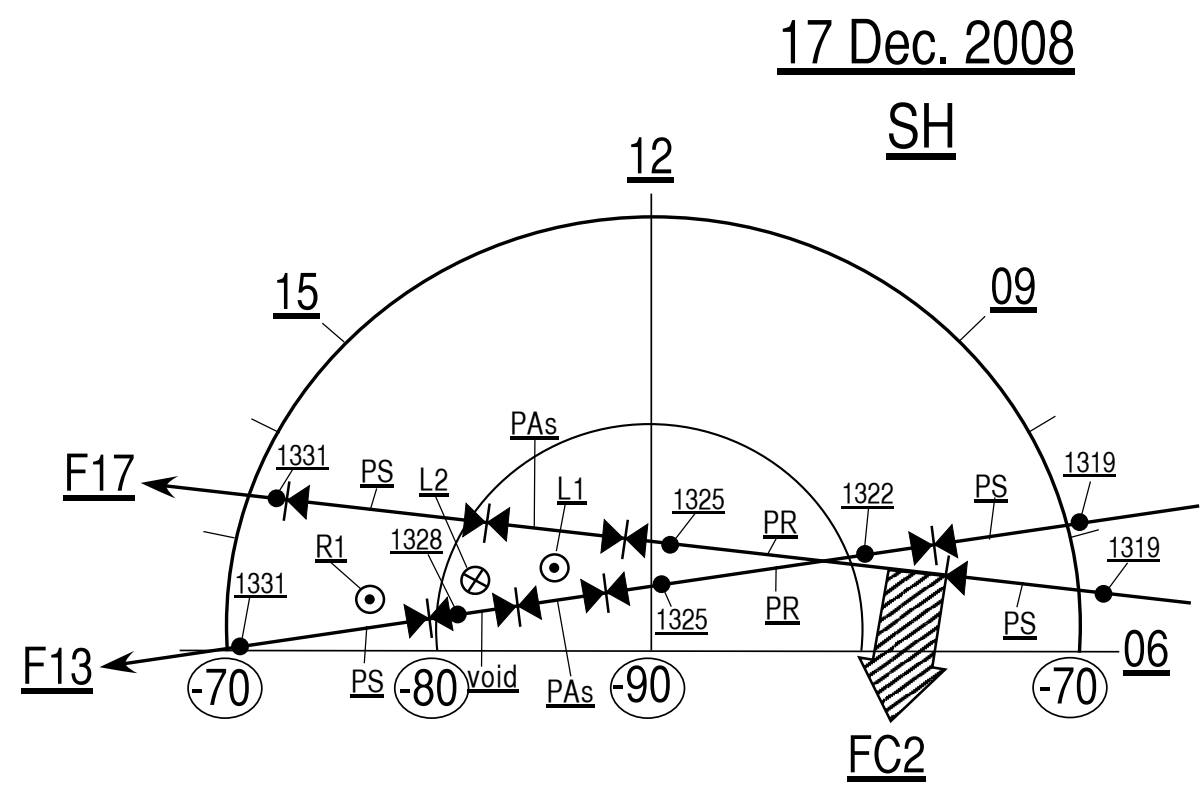

Fig. 6. Tracks of spacecraft DMSP F13 and F17 across the polar cap from dawn to dusk in the Southern Hemisphere (SH) during the interval 13:20-13:30 UT shown in MLT/MLAT coordinates. Regimes of particle precipitation (PS; PR; PAs; void), and Birkeland currents (R1; L1; L2) along the tracks are indicated. Flow channel FC 2 on the dawn side (07:00 MLT; $78^{\circ}$ MLAT) as detected by S/C F17 is marked by hatched arrow. The sector called "void" marks the dropout of polar rain in the regime of sunward convection (lobe cell) on the dusk side of the polar arcs (PAs) in the F13 data.

in Longyearbyen, Svalbard ( $75^{\circ}$ MLAT). The MSP field of view is indicated by the double-arrowed meridional line. Ground station Hornsund (HOR; $74^{\circ}$ MLAT) is marked by dotted circle. The location of the flow channel FC 2 (NH$\mathrm{dusk} / B_{\mathrm{y}}<0$ ) on the poleward side of the discrete oval aurora is marked by the hatched arrow.

Figure 11 shows SuperDARN observations of ion drift vectors and plasma flow lines for 14:10-14:12 UT. We notice the presence of flow channels FC 1 (noonward convection in early postnoon sector) and FC 2 (antisunward convection at dusk) in the dusk-side merging convection cell. We shall focus on the convection channel FC 2 at dusk (NHdusk $/ B_{\mathrm{y}}<0$ ), located in the Svalbard sector. This allows us to study the association between the FC 2 flow channel activity and ground magnetic deflections. The ground magnetic deflection observed in association with the convection event at 13:55-14:10 UT, recorded at station Hornsund (HOR) on Svalbard (see Fig. 10), is shown in the next figure.

Figure 12 shows the X-component magnetic deflection recorded from station HOR ( $74^{\circ}$ MLAT) on Svalbard during the interval 10:00-15:00 UT. A clear negative X-deflection appears after 13:55 UT when flow channel FC 2 had moved into a favourable position with respect to ground station HOR (Fig. 10) associated with an expansion of the polar cap during the interval 13:00-14:00 UT. The latter expansion is inferred from the auroral observations (not shown). This behaviour is consistent with the southward rotation of the IP cloud field during the interval 11:00-13:40 UT, as recorded by spacecraft Wind (see $B_{\mathrm{z}}$ panel in Fig. 2).

\subsection{Case 2: 20 November 2007}

We now discuss the second event, on 20 November 2007. Figure 13 now shows Wind SWE and MFI data for the $30 \mathrm{~h}$ interval, 14:00 UT, 19 November-20:00 UT, 20 November 2007. The format is the same as that of Fig. 2. Wind was situated at $(236,86,16) R_{\mathrm{E}}$ at 04:00 UT, 20 November and the convection delay is $\sim 1 \mathrm{~h}$. The observations during the interval bear a similarity to those of 17 December 2008. A magnetic cloud is seen between $\sim 00: 30-11: 30$ UT, 20 November. However, in this instance this transient is followed by a stream interaction region (Tsurutani et al., 2006) forming the leading edge of a faster stream. The interplanetary configuration is thus that of an ICME interacting with a faster stream. A shock driven by the MC is seen by Wind at $\sim 17: 15$ UT, 19 November.

A major difference with that of 17 December 2008 is the higher density and dynamic pressure. Here, during 00:00 UT-09:00 UT, 20 November, their values are (average + standard deviation): $8.89 \pm 4.55 \mathrm{~cm}^{-3}$ and $3.25 \pm 1.59 \mathrm{nPa}$, respectively. The magnetic field strength is also higher. Like 17 December 2008 the major component is the unipolar (westward) component. Again, an interval of clock angle $\approx 90^{\circ}$ is evident (between 04:00-09:00 UT, 20 November). The qualitiative similarities between the two events are overall very marked. But the quantitative differences are important in the ionospheric response as we shall see presently.

As in the previous case our analysis of magnetospheric/ionospheric data is restricted to an interval 


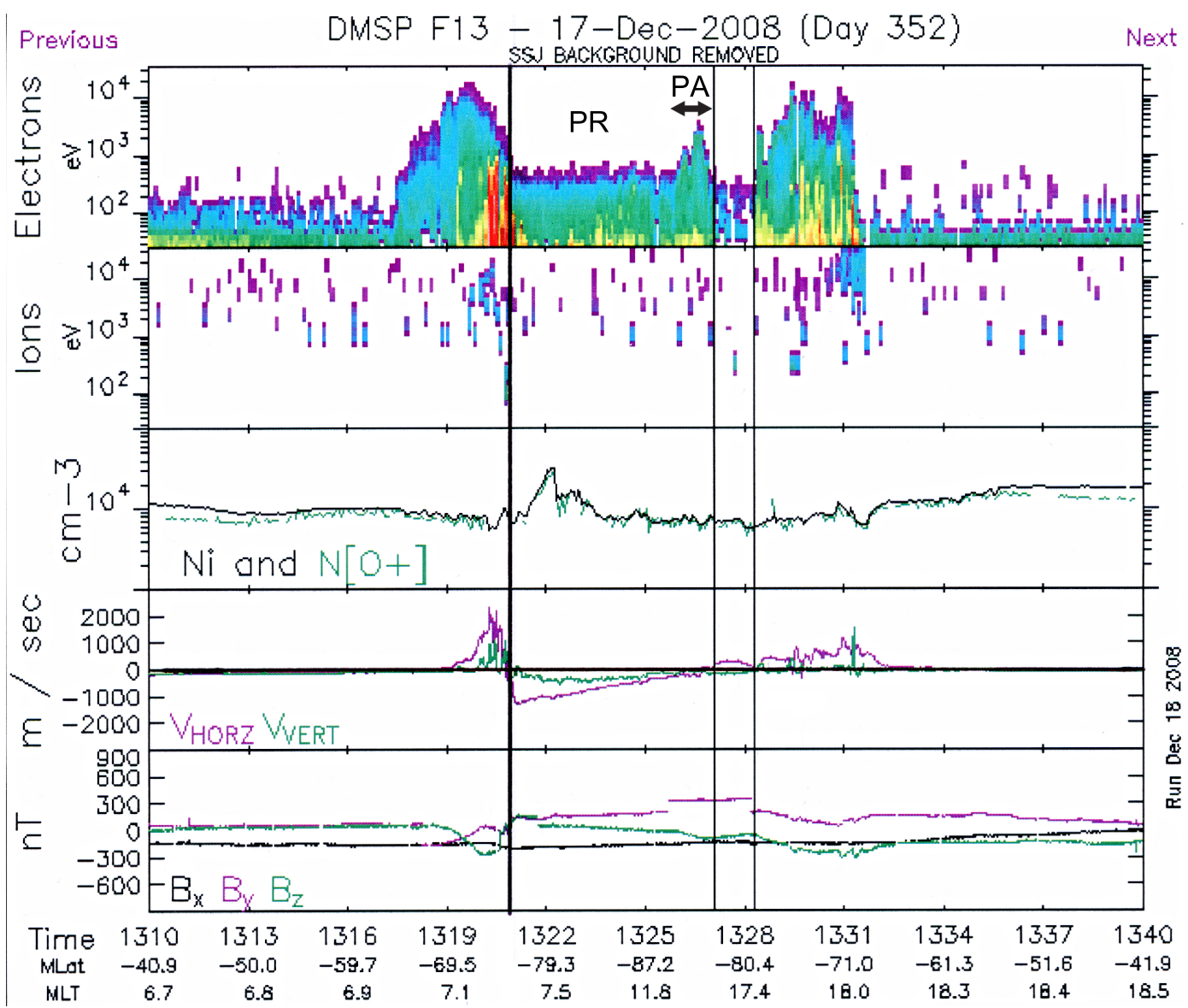

Fig. 7. Particle precipitation, ion drift, and magnetic deflections obtained by spacecraft DMSP F 13 during a Southern Hemisphere pass during 13:10-13:40 UT on 17 December 2008. Panels from top to bottom show electron precipitation flux, ion precipitation flux, ion densities, cross track ion drifts, and magnetic deflection components $B_{\mathrm{X}}, B_{\mathrm{y}}$, and $B_{\mathrm{Z}}$. Polar rain (PR), polar arcs (PA) and dropout of polar rain on the dusk side of the arcs have been marked.

(11:00-13:00 UT) placed at the rear end of the ICME (approx. 10:00-12:00 UT in the Wind plot). In the latter interval, delimited by the vertical guidelines in Fig. 13, $B_{\mathrm{y}}$ is strongly negative $\left(B_{\mathrm{y}}=-16 \mathrm{nT}\right)$. Contrary to case $1\left(B_{\mathrm{x}}=0\right)$ $B_{\mathrm{X}}$ is $-5 \mathrm{nT}$ in this case. The density is high $\left(10-40 \mathrm{~cm}^{-3}\right)$. This is the trailing edge of the ICME, i.e., the interplanetary correspondence to the high-density core of the 3-part structure of CMEs (Illing and Hundhausen, 1985, 1986; Low, 2001).

Figure 14 shows DMSP F13 data obtained during a crossing of the polar cap from dawn (6.8 MLT; $-78.3^{\circ}$ MLAT) to evening (19.5 MLT; $-70.7^{\circ}$ MLAT) in the Southern Hemisphere. We shall focus on the following features occurring in the interval 11:29-11:39 UT:

(i) dawn-dusk asymmetric ( $B_{\mathrm{y}}<0$ type) polar cap convection (panel four) and polar rain precipitation (top panel) in the central polar cap (between the third and fourth vertical guidelines). (ii) enhanced $(3 \mathrm{~km} / \mathrm{s})$ antisunward convection (flow channel FC 2) on the dawn-side polar cap boundary (6.8 MLT; -78 to $-80^{\circ}$ MLAT; $\left.11: 30 \mathrm{UT}\right)$.
Figure 15 shows DMSP F17 data obtained during a dawn to dusk crossing of the polar cap in the Southern Hemisphere. We shall focus on the following features of the observations in the interval 11:55-12:05 UT when the F17 spacecraft made a dawn-to-dusk traversal of the polar cap from (6.3 MLT; $-76^{\circ}$ MLAT) to (17.5 MLT; $-73.7^{\circ}$ MLAT):

(i) dawn-dusk asymmetric polar cap convection $\left(B_{\mathrm{y}}<0\right.$ type; panel four) and polar rain electron precipitation (top panel) in the polar cap, (ii) enhanced $(2.5 \mathrm{~km} / \mathrm{s})$ antisunward convection (flow channel FC 2) on the dawn side polar cap boundary.

Figure 16 shows the track of satellite DMSP F17 during the interval 11:56-12:05 UT. Flow channel FC 2 at dawn is marked. We note that the F13 satellite (data in Fig. 14) crossed the same dawn-side MLT sector $25 \mathrm{~min}$ earlier (11:30 UT). Similar FC 2 convection profiles (maximizing at 3 and $2.5 \mathrm{~km} / \mathrm{s}$ ) were identified in the two cases centered at $78^{\circ}$ MLAT/5.8 MLT (F13 at 11:30 UT) and at $77^{\circ}$ MLAT/6.3 MLT (F17 at 11:56 UT), respectively. 


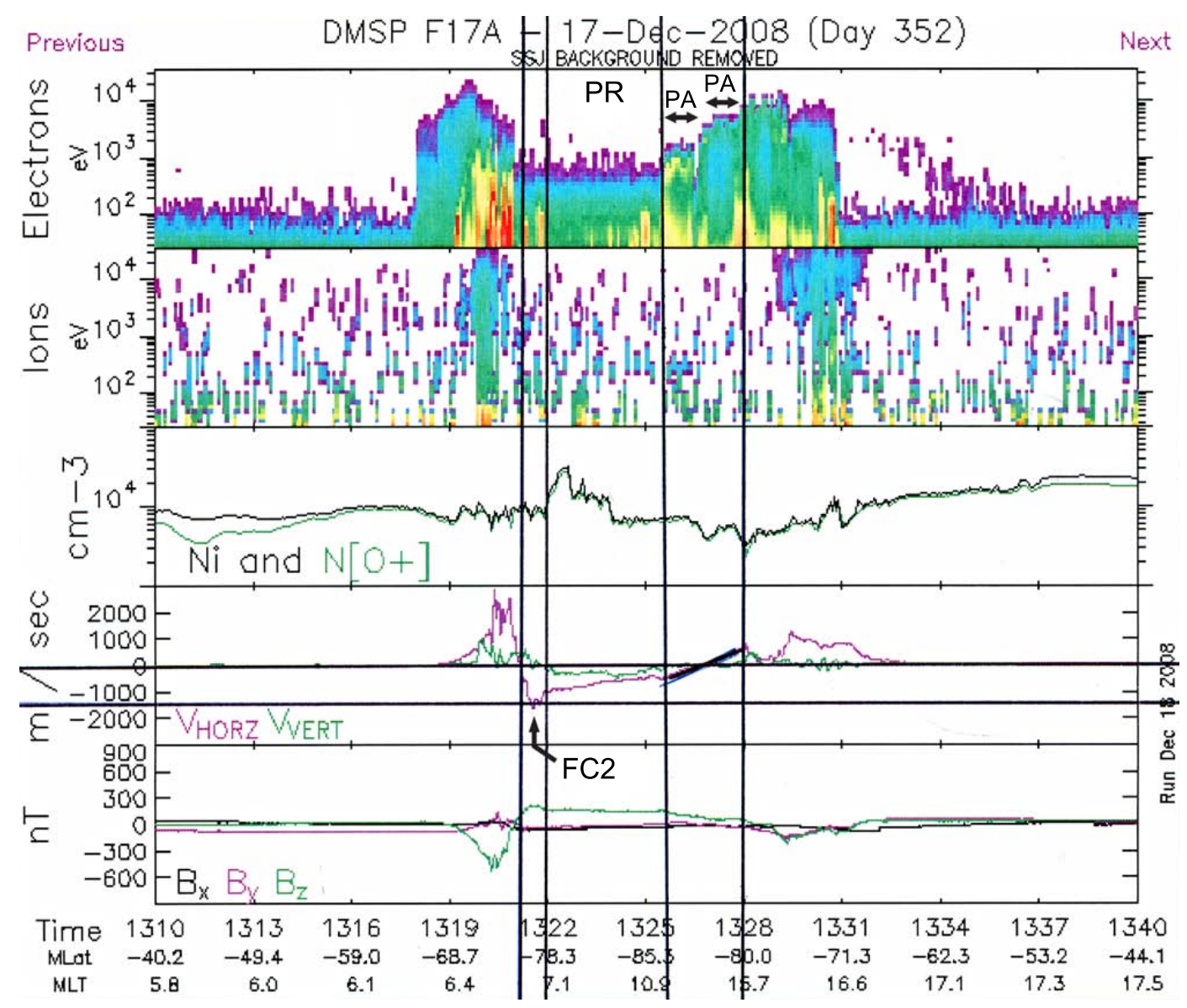

Fig. 8. DMSP F17 Southern Hemisphere data for the interval 13:10-13:40 UT on 17 December 2008. Same format as in Fig. 7. Flow channel FC 2 of category SH-dawn $/ B_{\mathrm{y}}<0$ is marked. Polar arcs (PA) are located in region of flow shear (ion drift gradient) marked between the third and the fourth guidelines.

Figure 17 shows a SuperDARN spatial plot in MLT/MLAT coordinates for 11:52-11:54 UT illustrating the presence of flow channel (enhanced antisunward convection) centered at 15:00 MLT/72-73 ${ }^{\circ}$ MLAT, i.e., near the southern tip of the arctic island Svalbard. This is identified as FC 2 of category $\mathrm{NH}$-dusk $/ B_{\mathrm{y}}<0$. FC 2 is seen in the vicinity of the Svalbard ground station Hornsund (HOR) located at $73^{\circ}$ MLAT, whose approximate location is indicated in the figure. In the next figure we shall report ground magnetometer readings from stations on Svalbard including HOR.

Figure 18 shows $\mathrm{X}$-component deflections during the interval 10:30-13:00 UT detected at the Svalbard IMAGE stations (http://www.geo.fmi.fi/image) Ny Ålesund (NAL; $75^{\circ}$ MLAT), Hornsund (HOR; $74^{\circ}$ MLAT), and Bear Island (BJN; $71^{\circ}$ MLAT). A series of six major deflection events are identified during the interval 11:00-12:40 UT when the stations swept through the $\sim 14: 30-16: 10$ MLT sector. Arrows in the HOR-BJN panels mark deflection maxima at these stations (71-74 ${ }^{\circ}$ MLAT) centered at 11:05, 11:18, 11:42, 11:52, 12:12, and 12:32 UT. The event at 11:52 UT corresponds to the time of the SuperDARN convection plot shown in Fig. 17. We notice that the event duration time is $5-10 \mathrm{~min}$. The deflections are weaker on the northernmost station (NAL) suggesting that this location was farther away from the center of the convection channel.

\section{Summary and discussion}

We reported observations of aspects of polar cap precipitation and convection states in both hemispheres during two selected intervals of the Earth passage of two ICMEs which were accompanied by different levels of external forcing of the magnetosphere. The observations in the Northern and Southern Hemispheres were obtained by SuperDARN radars (north) and DMSP spacecraft (south), respectively. The application of SuperDARN plasma convection data in the Svalbard sector allowed us to study the ground magnetic effect associated with flow channel FC $2\left(\mathrm{NH}-\right.$ dusk $\left./ B_{\mathrm{y}}<0\right)$ located on the dusk $(\mathrm{NH})$ side of the polar cap during the prevailing $B_{\mathrm{y}}<0$ conditions in the two IP clouds. 


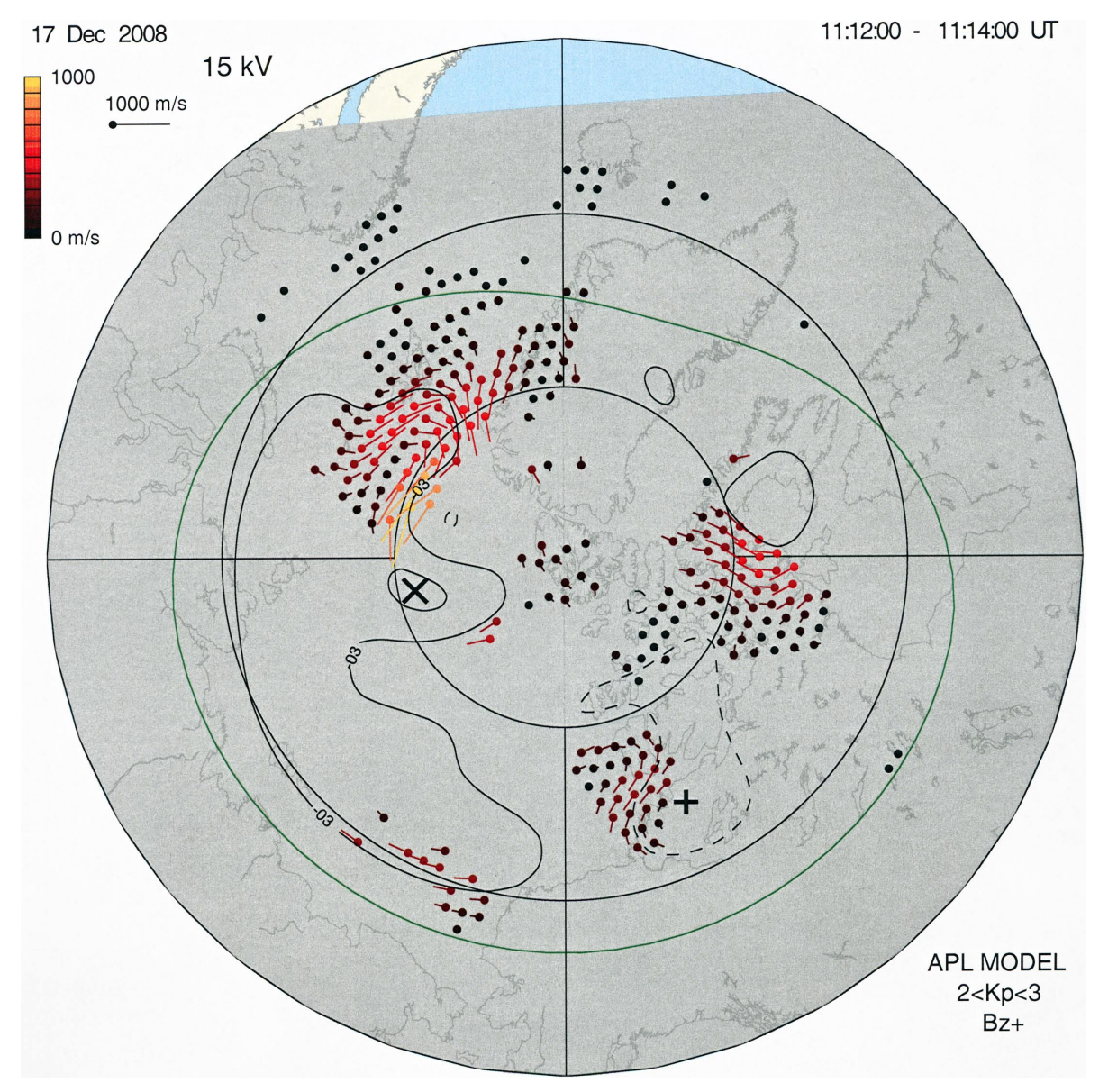

Fig. 9. SuperDARN spatial convection plot for 11:12-11:14 UT, 17 December 2008 representing flow channel FC 2 of type NH-dusk/ $B_{\mathrm{y}}<0$. The coordinate system is MLAT/MLT. The Sun is at the top and dusk is to the left.

The observations may be summarized as follows:

1. We document the presence of flow channel FC 2 in both these solar minimum ICME cases. The effect $(\mathrm{NH}-$ dusk $/ B_{\mathrm{y}}<0$ and SH-dawn $\left./ B_{\mathrm{y}}<0\right)$ is most pronounced in our case 2 which is characterized by strong solar wind forcing $\left(\mathrm{CPCP}_{\text {Boyle }}=120-180 \mathrm{kV}\right)$.

2. In case 1 , under moderate solar wind forcing $\left(\mathrm{CPCP}_{\text {Boyle }}=80 \mathrm{kV}\right)$, we observe a weak or absent FC 2 flow channel in the Southern Hemisphere. FC 2 in the north is clearly present around 14:00 UT (when $B_{\mathrm{Z}}$ in the IP cloud had decreased to $-4 \mathrm{nT}$ ), as demonstrated in Fig. 11. The different FC 2 responses in the two IP cloud cases (and within one cloud interval) may reflect a dependence on the level of solar wind forcing.

3. For the first time we document the presence of a Svalgaard-Mansurov (S-M) effect associated with flow channel FC 2, this time in the form of category $\mathrm{NH}$ dusk $/ B_{\mathrm{y}}<0$. In our case 2 this S-M effect appears as a series of $5-10 \mathrm{~min}$. long negative $(50-100 \mathrm{nT})$ $\mathrm{X}$-component deflections in the region of the FC 2 flow channel (71-74 ${ }^{\circ}$ MLAT; 14:30-16:00 MLT) in the winter hemisphere. From these ground deflections on 20 November 2007 we infer a series of convection/precipitation events at the polar cap boundary in the 14:30-16:10 MLT sector. From these data we may infer that flow channel FC 2 is pulsed in this particular case. A ground magnetic effect is also documented in case 1 after 13:55 UT when the FC 2 channel had moved into a favourable position with respect to ground station Hornsund (HOR).

4. A lobe cell with polar arcs is present in the Southern (summer) Hemisphere in the low-density $\left(<1-2 \mathrm{~cm}^{-3}\right)$ case 1 under the prevailing $B_{\mathrm{x}}=0$ conditions. This suggests the previous indication that dipole tilt (season) determines the inter-hemisphere asymmetry when IMF $B_{\mathrm{x}}$ is small (see Crooker and Rich, 1993). According to Crooker and Rich (1993) lobe reconnection is favoured in the summer hemisphere. In our case $2\left(B_{\mathrm{x}}<0\right)$ lobe cell convection and polar arcs are not observed in the south despite the favoured dipole tilt. This may be due 


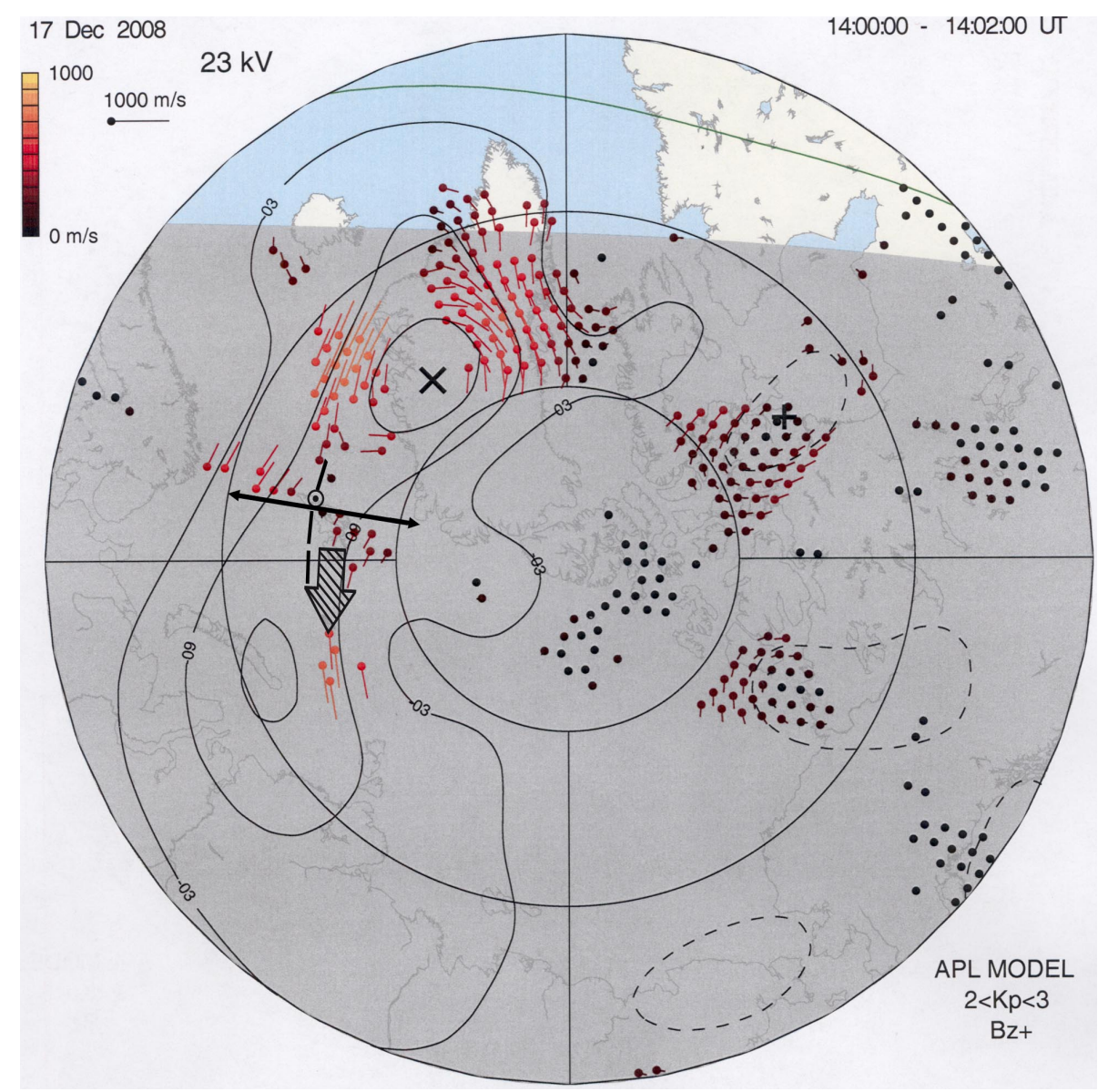

Fig. 10. SuperDARN spatial convection plot for 14:00-14:02 UT. Ground station Hornsund (HOR) on Svalbard (17 MLT; $74^{\circ}$ MLAT), flow channel FC 2 and the approximate location of discrete aurora (poleward boundary/dashed line) as observed by meridian scanning photometer (MSP) in Longyearbyen ( $75^{\circ}$ MLAT) have been marked by dotted circle, hatched arrow (in addition to the ion drift vectors in the antisunward direction), and double-arrowed meridional line, respectively. The latter is the Longyearbyen MSP field of view in the the $630.0 \mathrm{~nm}$ emission line.

to the negative IMF $B_{\mathrm{x}}$ which favours lobe reconnection in the Northern Hemisphere.

5. The polar arc precipitation appears as accelerated polar rain (see Carlson and Cowley, 2005) in a regime where outward-directed Birkeland current is expected in the center of the lobe cell in the Southern Hemisphere (see the L1-current in Fig. 1 which has been documented by Eriksson et al., 2002). The presence of the L1-current is confirmed by the present data (see negative $B_{\mathrm{Z}}$-gradient in Fig. 7).

6. We document the dropout of polar rain precipitation in the regime of sunward convection on the dusk side of the lobe cell polar arcs where previous study (see Eriksson et al., 2002 and the present work) documented the presence of inward-directed Birkeland current (see L2 FAC in Fig. 1 and positive $B_{\mathrm{Z}}$-gradient in Fig. 7). This may be explained by the presence of a field-aligned potential drop in the regime of inward-directed Birkeland return current (L2) which prevents the polar rain electrons from coming down into the ionosphere. Thus, this polar rain dropout may be seen as an analogy to the presence of black aurora observed in the downwarddirected return current regime between multiple auroral arcs in the auroral oval (Marklund et al., 2001). This effect is different from the normal IMF $B_{\mathrm{y}}$ related dawndusk asymmetry of polar rain precipitation (see review by Newell et al., 2009).

7. The absence of polar arcs in case 2 (20 November 2007) may be partly due to the high plasma density density $\left(10-20 \mathrm{~cm}^{-3}\right)$ in this ICME case. This is consistent with a previous result indicating that polar arcs under the prevailing southwest IMF conditions are favoured by low solar wind density (Frey et al., 2003). This effect comes in addition to the negative $B_{\mathrm{x}}$ component which is unfavourable for lobe reconnection to occur in the Southern Hemisphere. 


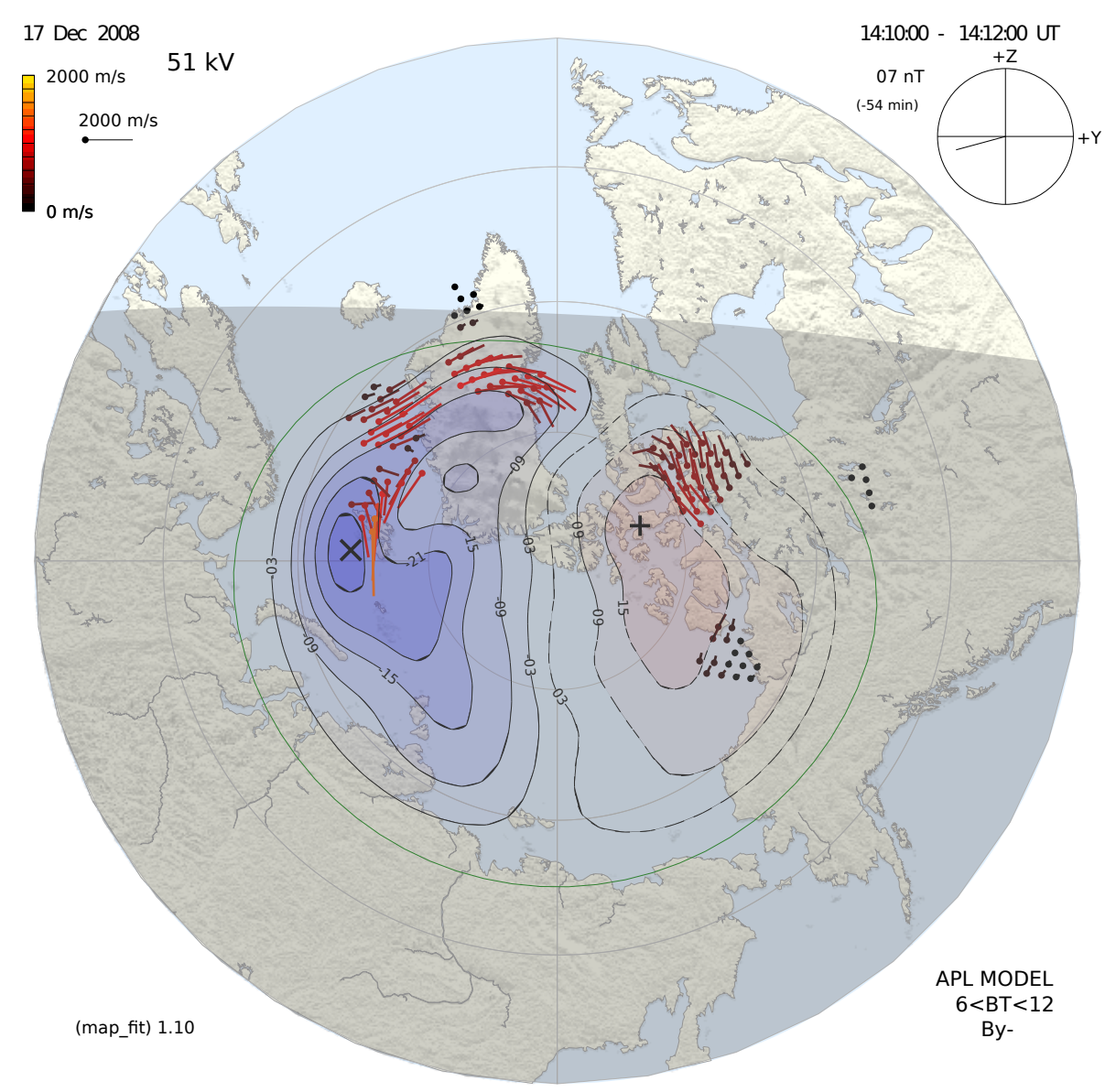

Fig. 11. SuperDARN spatial convection (ion drift) plot for 14:10-14:12 UT. A channel of enhanced antisunward convection (FC 2 of type $\mathrm{NH}$-dusk $\left./ B_{\mathrm{y}}<0\right)$ is seen at dusk, in the Svalbard sector. The coordinate system is MLT/MLAT.

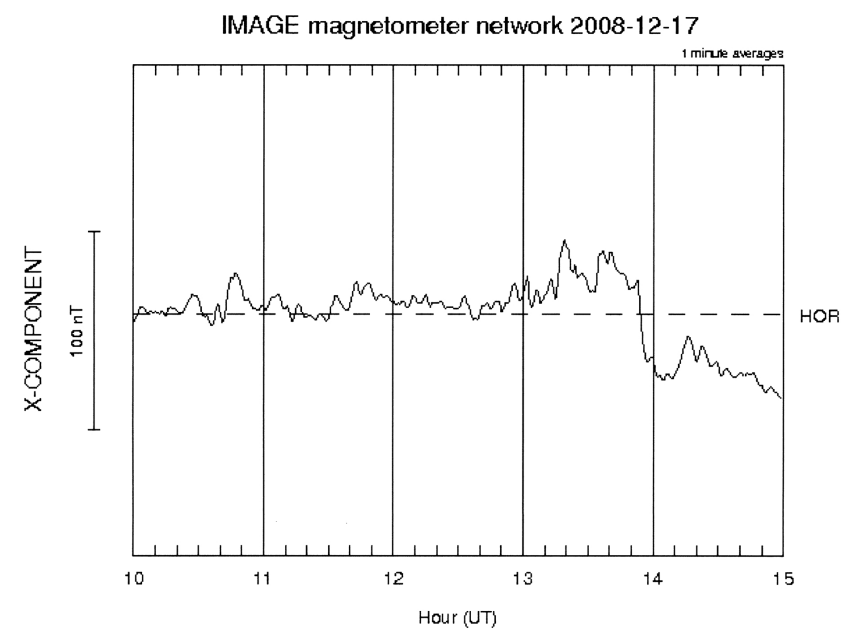

Fig. 12. X-component magnetic deflection recorded from station HOR ( $74^{\circ}$ MLAT) on Svalbard. We shall focus on the negative Xdeflection after 13:55 UT. This magnetic deflection reflects the Hall current associated with flow channel FC 2 (see Fig. 10.
We note that one variant of the FC 2 flow channel in the IMF $B_{\mathrm{y}}<0$ cases reported here $\left(\mathrm{NH}-\mathrm{dusk} / B_{\mathrm{y}}<0\right)$ occur in the regime of $\mathrm{C} 1$ Birkeland current flowing into the ionosphere (see Fig. 1). Such enhanced $\mathbf{E}$-fields in the regime of downward-directed Birkeland current have been observed by the Freja and FAST satellites (Marklund et al., 1997; Carlson et al., 1998) and at higher altitudes by Cluster (Karlsson et al., 2004). The latter observations are consistent with the model of the connection between Birkeland current, current closure and ionospheric cavity formation as proposed by T. Karlsson, N. Brenning, O. Marghitu, G. Marklund and S. Buchert (arXiv:0704.1610v1 [physics.space-ph], 2007). This model applies to night/wintertime conditions of low background conductivities. However, this restriction does not apply to our FC 2 flow channel. We find that generally FC 2 flows are reduced, but not necessarily absent, in the case of a sunlit ionosphere. We explain this enhanced antisunward flow as a signature of efficient momentum coupling from the solar wind along old-open field lines down to the polar cap ionosphere immediately poleward of the precipitation boundary at dawn/dusk MLTs. The interconnection topology 


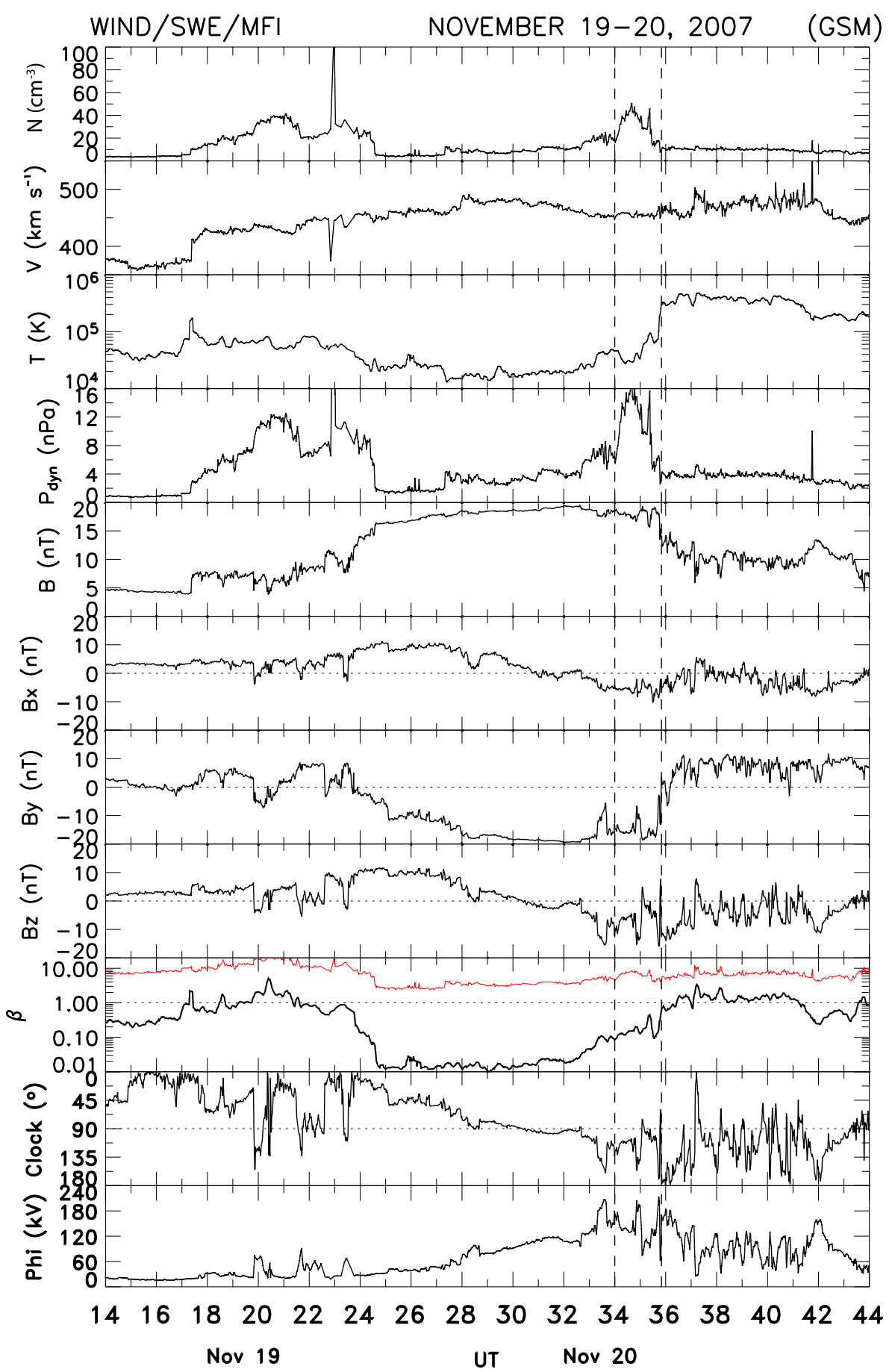

Fig. 13. Wind data for the interval 14:00 UT, 19 November-20:00 UT, 20 November 2007. The Wind interval (10:00-11:50 UT, 20 November) corresponding to the low-altitude observations discussed in this paper is marked by vertical guidelines. Same format as in Fig. 2.

is indicated in Fig. 1. We point out the DMSP F17 evidence of $\mathrm{C} 2$ (inward and positive $B_{\mathrm{Z}}$ gradient) and $\mathrm{C} 1$ (outward and negative $B_{\mathrm{Z}}$ gradient) in Figs. 8 and 15 (the interval 11:5612:02 UT).

We next place the FC 2 activity in the context of convection and auroral phenomena located on newly open field lines. The flow channel on newly open field lines (LLBL/cusp precipitation) we shall refer to as FC 1. It is often observed in the form of pulsed ionospheric flows (PIFs) (also referred to as poleward moving radar auroral forms; PMRAFs) in close association with poleward moving auroral forms (PMAFs) and poleward propagating ground magnetic 


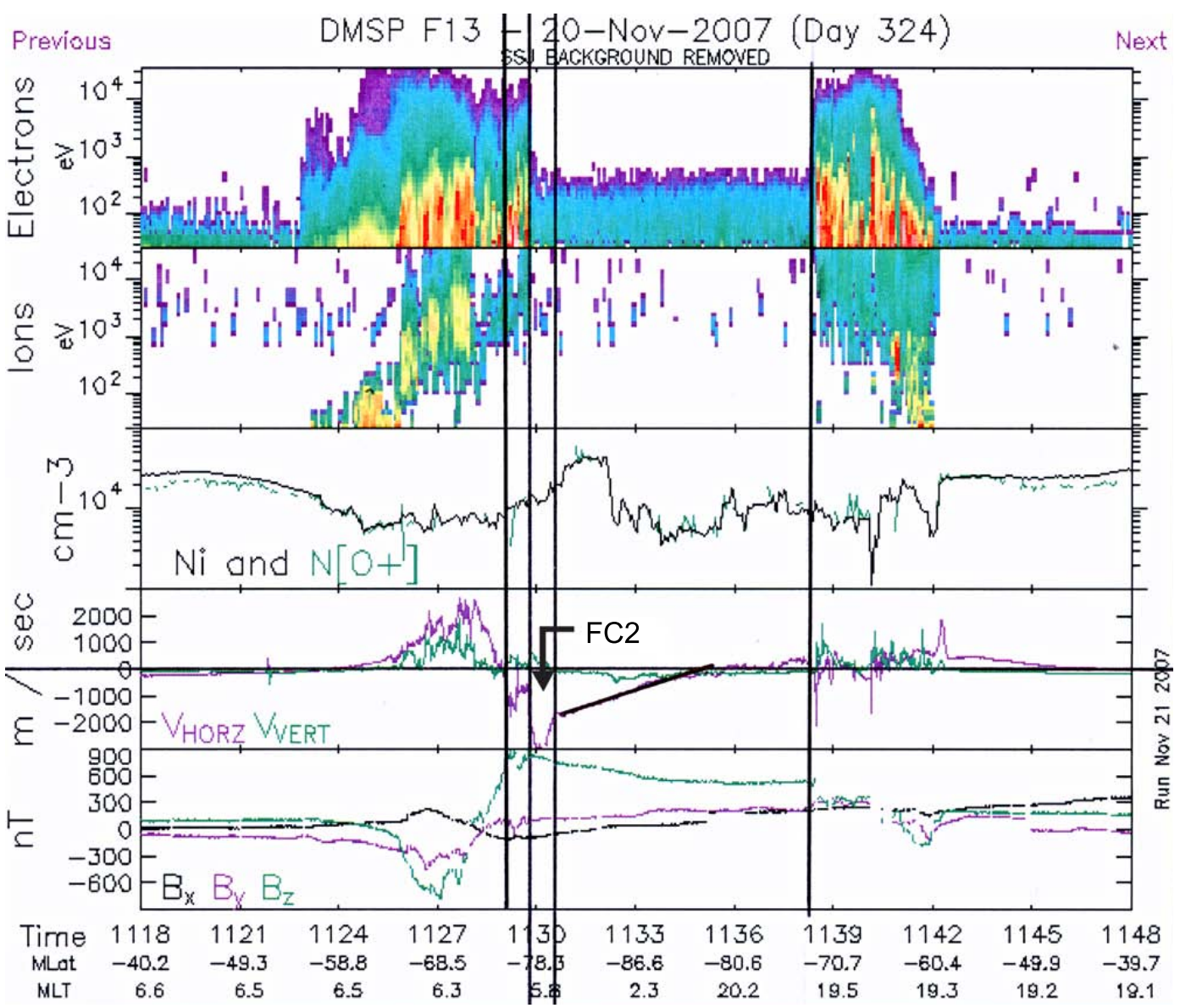

Fig. 14. DMSP data obtained by spacecraft F13 in the Southern Hemisphere during the interval 11:18-11:48 UT on 20 November 2007. Same format as in Fig. 7. Flow channel FC 2 of category SH-dawn $/ B_{\mathrm{y}}<0$ is marked.

deflections (Øieroset et al., 1997; Provan et al., 1999, 2002; Wild et al., 2003).

A schematic illustration of the IMF $B_{\mathrm{y}}<0$ variant of these phenomena (Birkeland currents; auroral forms; plasma convection) is given in Fig. 19. The main focus here is on the two types of flow channels FC 1 and FC 2 and the associated auroral forms. Flow channels FC 1 are marked in the prenoon and postnoon sectors while FC 2 is marked at dusk. The illustration of the postnoon sector activities is based on observations on two different days (30 November 1997 and 21 January 2001) with similar IMF $B_{\mathrm{y}}<0$ conditions (see Sandholt and Farrugia, 2007a). The Birkeland current sheets (R2, R1, C2, C1) were obtained by the polar orbiting spacecraft FAST (Jan. 21, 2001) and DMSP F13 (15:25-15:34, 21 January 2001 and 11:24-11:32, 30 November 1997) as reported by Farrugia et al. (2004). On 21 January 2001 flow channel FC 2 was detected at approx. 13:00 MLT by the Sondrestrom radar (see Fig. 13 in Farrugia et al. (2004)) and at dusk by the DMSP F13 spacecraft. The prenoon aurora (PMAFs/prenoon) and associated plasma convection features (30 November 1997) schematically marked in the figure were reported by Thorolfsson et al. (2000).
Here we shall direct attention to contrasts between the FC 1 and FC 2 associated phenomena. FC 1 is accompanied by the following features:

1. LLBL or cusp type precipitations (mainly in the 09:0011:00 and 13:00-15:00 MLT sectors),

2. early stages of poleward moving auroral forms (PMAFs),

3. poleward propagating pulsed ionospheric flows (PIFs),

4. poleward propagating ground magnetic deflections (DPY).

In contrast to this, flow channel FC 2 is accompanied by:

1. mantle or polar rain precipitation, mainly in the 15:0018:00 MLT sector (NH) for the given $B_{\mathrm{y}}<0$ condition,

2. the highest-latitude stages of PMAFs/postnoon $/ B_{\mathrm{y}}<0$ and PMAFs/prenoon $/ B_{\mathrm{y}}>0$,

3. a series of ground magnetic deflection events in the 14:00-16:30 MLT sector (the 20 November 2007 case), 


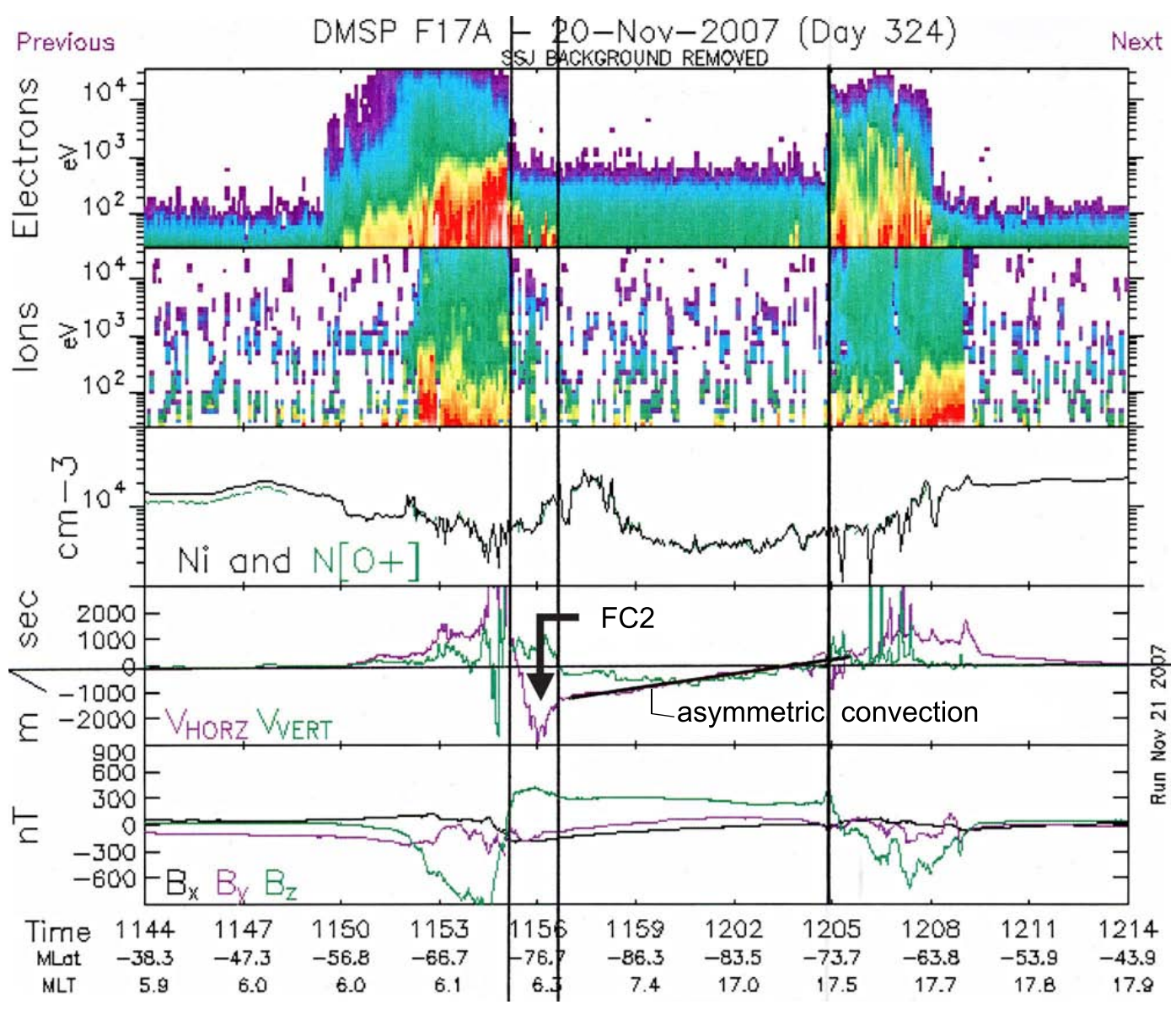

Fig. 15. DMSP data obtained by spacecraft F17 in the Southern Hemisphere during the interval 11:44-12:14 UT on 20 November 2007. Same format as in Fig. 7. Flow channel FC 2 of category SH-dawn $/ B_{\mathrm{y}}<0$ and asymmetric antisunward convection in the central polar cap have been marked.

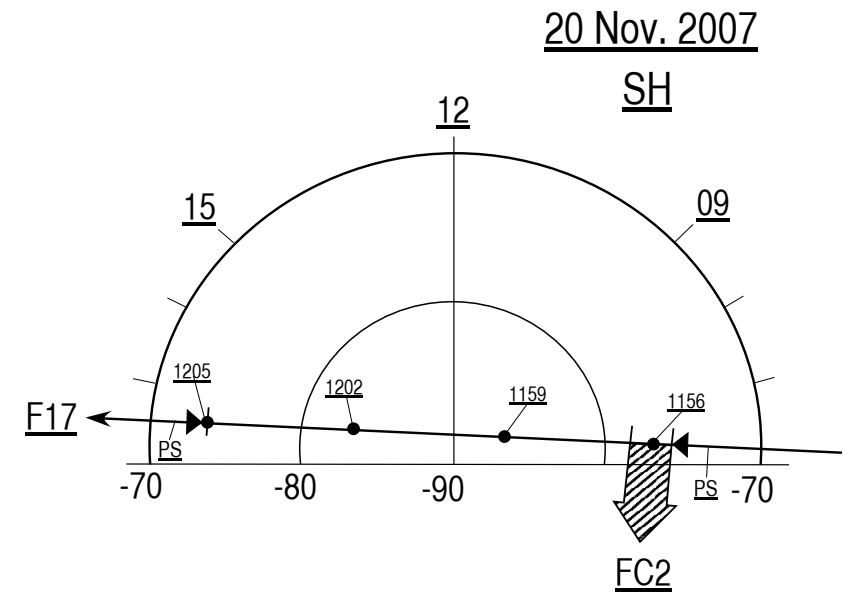

Fig. 16. Track of spacecraft DMSP F17 during the interval 11:5612:05 UT shown in MLT/MLAT coordinates. Flow channel FC 2 at dawn is marked. and the poleward propagation component in these events is generally absent (see Fig. 18).

The absence of the poleward propagation component in the FC 2-related events (feature (iii)) is in sharp contrast to the FC 1-related activities (Øieroset et al., 1997). The PMAFs/postnoon/ $B_{\mathrm{y}}<0$ marked along the 15:00 MLT meridian in Fig. 19 refer to observations by meridian scanning photometer (MSP) and all-sky camera (field of view indicated by circle) on 30 November 1997 showing a clear poleward propagation in three stages (red forms) with the northernmost stage (weak $630.0 \mathrm{~nm}$ emission) corresponding to mantle-type precipitation and FC 2 (see Figs. 2, 3 and 4 in Sandholt and Farrugia, 2007a). In a previous study we documented the association between the high-latitude stage of PMAFs/prenoon $/ B_{\mathrm{y}}>0$ and FC 2 (Sandholt and Farrugia, 2007b).

In summary, in the present paper (discussed in the context of previous work) we have used the strong and moderate forcing of the magnetosphere by IP magnetic clouds to establish a more comprehensive picture of the dayside and 


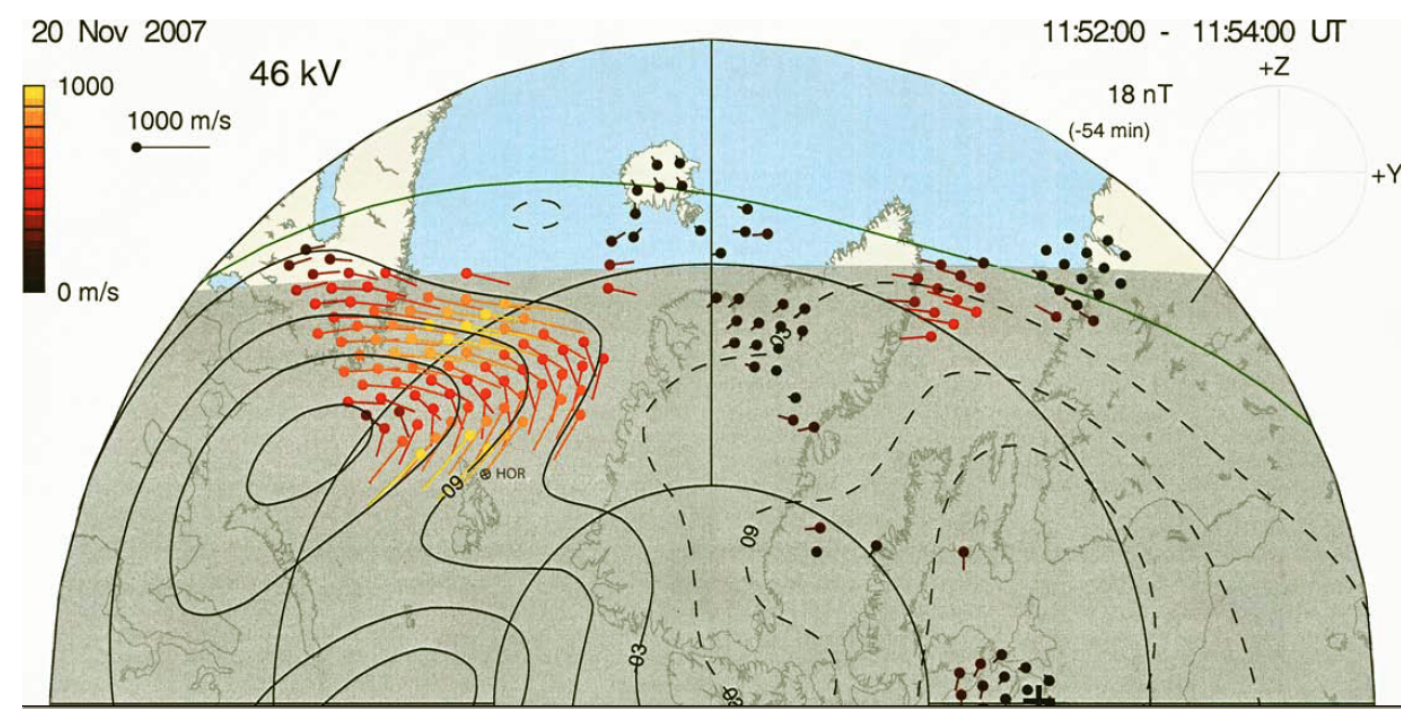

Fig. 17. SuperDARN ion drift data for 11:52-11:54 UT, 20 November 2007. Flow channel FC of category FC $2-\mathrm{NH}-\mathrm{dusk} / B_{\mathrm{y}}<0$ is seen at 15:00 MLT $/ 72-73^{\circ}$ MLAT. The approximate location of the magnetometer station at Hornsund (HOR) has been marked.

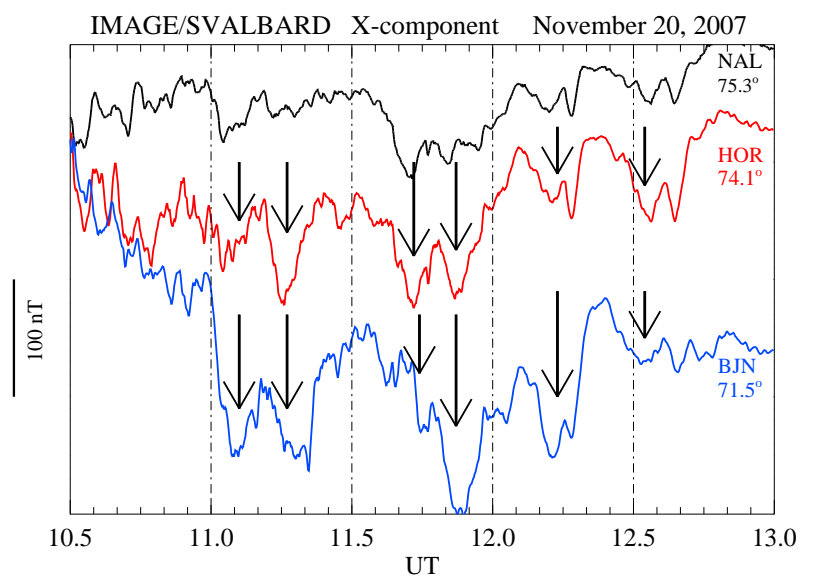

DPY magnetic deflections (SM effect): Pulsed antisunward convection at post-noon MLTs

Fig. 18. IMAGE Svalbard X-component deflections at stations NAL ( $75^{\circ}$ MLAT), HOR ( $74^{\circ}$ MLAT), and BJN ( $71^{\circ}$ MLAT) for the interval 10:00-13:00 UT, 20 November 2007. Major deflection events (negative deflection maxima) are marked by arrows in the HOR and BJN panels at 11:05, 11:18, 11:42, 11:52, and 12:12 UT.

polar cap particle precipitation morphology during southwest $\left(B_{\mathrm{z}}<0 ; B_{\mathrm{y}}<0\right)$ IMF conditions and the relationship with plasma convection channels FC 1 and FC 2. In our view this represents a new and improved basis for the discussion of solar wind-magnetosphere-ionosphere coupling. Elements of the IMF $B_{\mathrm{y}}<0$ variant of this coupling during Earth passage of IP clouds are indicated in our Fig. 1.

Essential features of the precipitation morphology are:

1. "the midday gap aurora" (strongly attenuated emission intensity at noon),
2. different variants of PMAF activities appearing on both sides of "the midday gap aurora" at noon, i.e., four variants sorted by MLT sector (prenoon versus postnoon) and IMF $B_{\mathrm{y}}$ polarity,

3. polar cap arcs appearing in the two variants $\mathrm{NH}$ dusk $/ B_{\mathrm{y}}>0$ (see Sandholt et al., 2006) and SHdusk $/ B_{\mathrm{y}}<0$ (see DMSP Figs. 3, 4, and 6) during $B_{\mathrm{z}}<0$ conditions,

4. polar rain dropout in the SH-dusk sector of the polar cap where the Birkeland current (our L2 current) is inwarddirected in the IMF $B_{\mathrm{y}}<0$ case (see the positive $B_{\mathrm{z}}$ gradient in Fig. 7).

In the present work we documented the presence of a specific ground magnetic deflection mode (a series of six 510 min long deflections; see Fig. 18) associated with flow channel FC $2\left(\mathrm{NH}-d u s k / B_{\mathrm{y}}<0\right)$. The intermittent nature of the magnetic deflections on 20 November is consistent with the pulsed nature of flow channel FC 2 in this particular case. This may indicate a relationship with FTEs (see e.g. Sibeck and Lin, 2010, and references therein).

As tasks for the future investigation of flow channel FC 2 we note the following:

1. Relationship with PMAFs:

The detailed relationship with the higher-latitude stages of PMAFs/prenoon $/ B_{\mathrm{y}}>0$ and PMAFs/postnoon/ $B_{\mathrm{y}}<$ 0 (see Fig. 19) should be investigated further.

2. Temporal structure and relationship with aurorae at dawn/dusk polar cap boundary:

A better documentation of the temporal behaviour of flow channel FC 2 is essential. Is it typically pulsed 


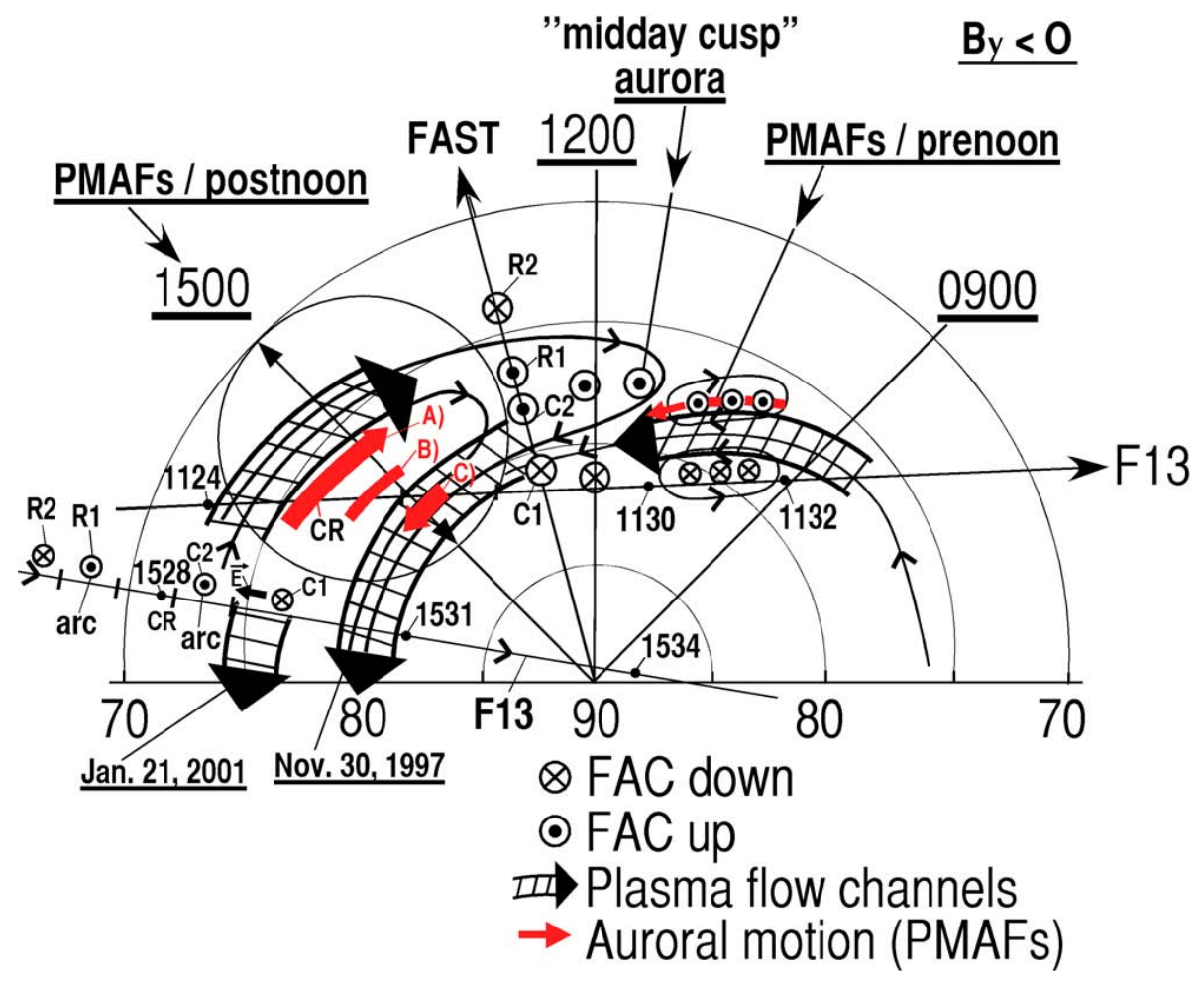

Fig. 19. Schematic illustration of plasma flow channels and aurorae located on newly open and old open field lines under IMF $B_{\mathrm{y}}<0$ conditions. Flow channels FC 1 are characterized by noonward convections in the prenoon and postnoon sectors. FC 2 shows enhanced antisunward convection at dusk. The two FC 2 channels marked at dusk refer to two different days of observations (21 January 2001 and 30 November 1997). Auroral observations in the prenoon (PMAFs/prenoon) and postnoon (PMAFs/postnoon) sectors were obtained on 30 November 1997. Tracks of spacecraft DMSP F13 from dusk to dawn refer to two intervals on different days (11:24-11:32 UT, 30 November 1997 and 15:25-15:34 UT, 21 January 2001). Relationships between latitude profiles of Birkeland currents (C1-C2-R1-R2) and poleward moving auroral forms (PMAFs; marked red) are indicated. The coordinate system is MLAT/MLT. Dusk is to the left.

or quasi-steady? Related to this we want to study the dynamics of the aurora bordering the FC 2 flow channel on its equatorward side (see the geometry in Fig. 10).

\section{Spatial structure:}

The spatial structure of the FC 2 flow channel, with emphasis on the longitudinal (MLT) extent (connection to the dayside or not) of the events, needs further study.

4. IMF dependence:

A study of the FC 2 IMF dependence is lacking. The typical situation is for FC 2 to be present either on the dawn or dusk side depending on the IMF $B_{\text {y }}$ polarity. However, we need to determine the IMF clock angle range under which this normal mode of FC 2 is present. We are also curious about the possible presence of FC 2 on both sides (dusk and dawn) of the polar cap boundary during intervals of strongly southward IMF orientation (small $B_{\mathrm{y}}$ component). In one case studied so far this specific mode was present. Furthermore, we want to study the detailed FC 2 response to sharp changes in the IMF $B_{\mathrm{y}}$ polarity.
5. Contribution to the cross polar cap potential (CPCP): We want to document the contribution of FC 2 to the CPCP $\left(\Phi_{\mathrm{PC}}\right)$ under various levels of solar wind forcing. A preliminary study indicates that it can contribute 20 $50 \%$ to $\Phi_{\mathrm{PC}}$ in the case of dark polar cap ionosphere and under moderate to strong solar wind forcing. This illustrates the crucial importance of flow channel FC 2 in such cases.

Acknowledgements. Access to the DMSP data base (https://swx. plh.af.mil) was kindly provided by Air Force Geophysics Research Laboratory, Hanscom, Mass. Ground magnetograms from the Svalbard IMAGE chain of ground stations were obtained from http://www.geo.fmi.fi/image. Thanks to Ari Viljanen and Truls Lynne Hansen for Svalbard magnetograms. SuperDARN convection plots were obtained from http://superdarn.jhuapl.edu. Highresolution SuperDARN data were provided by Kjellmar Oksavik. Work at University of Oslo is supported by the Norwegian Research Council (NFR). Work at UNH is supported by NASA grants NNG05GG25G and Wind grant NNX08AD11G.

Topical Editor R. Nakamura thanks S. Eriksson, T. Moretto Jorgensen, and another anonymous referee for their help in evaluating this paper. 


\section{References}

Borovsky, J. E., Lavraud, B., and Kuznetsova, M. M.: Polar cap saturation, dayside reconnection, and changes to the magnetosphere, J. Geophys. Res., 114, A03224, doi:10.1029/2009JA014058, 2009.

Boyle, C. B., Reiff, P. H., and Hairston, M. R.: Empirical polar cap potentials, J. Geophys. Res., 102, 111-125, 1997.

Burlaga, L. F., Sittler, E., Mariani, F., and Schwenn, R.: Magnetic loop behind an interplanetary shock: Voyager, Helios, and IMP8 observations, J. Geophys. Res., 86, 6673-6684, 1981.

Carlson, C. W., McFadden, J. P., Ergun, R. E., Temerin, M., Peria, W., Mozer, F. S., Klumpar, D. M., Shelley, E. G., Peterson, W. K., Mobius, E., Elphic, R., S. R., Cattell, C. A., and Pfaff, R.: Fast observations in the downward auroral current region: Energetic upgoing electron beams, parallel potential drops, and ion heating, Geophys. Res. Lett., 25, 2017-2020, 1998.

Carlson, H. C. and Cowley, S. W. H.: Accelerated polar rain electrons as the source of Sun-aligned arcs in the polar cap during northward IMF conditions, J. Geophys. Res., 110, A05302, doi:10.1029/2004JA010669, 2005.

Crooker, N. U. and Rich, F. J.: Lobe cell convection as a summer phenomenon, J. Geophys. Res., 98, 13403-13407, 1993.

Crooker, N. U., Lyon, J. G., and Fedder, J. A.: MHD model merging with IMF $B_{y}$ : Lobe cells, sunward polar cap convection, and overdraped lobes, J. Geophys. Res., 103, 9143-9151, 1998.

Davis, C. J., Davies, J. A., Lockwood, M., Roillard, A. P., Eyles, C. J., and Harrison, R. A.: Stereoscopic imaging of an Earth-impacting solar coronal mass ejection: A major milestone for the STEREO mission, Geophys. Res. Lett., 36, L08102, doi:10.1029/GL038021, 2009.

Eriksson, S., Bonnell, J. W., Blomberg, L. G., Ergun, R. E., Marklund, G. T., and Carlson, C. W.: Lobe cell convection and fieldaligned currents poleward of the Region 1 current system, J. Geophys. Res., 107(A8), 1185, doi:10.1029/2001JA005041, 2002.

Eriksson, S., Peria, W. J., Bonnell, J. W., Su, Y. J., Ergun, R. E., Tung, Y. K., Parks, G. K., and Carlson, C. W.: Lobe cell convection and polar cap precipitation, J. Geophys. Res., 108(A5), 1198, doi:10.1029/2002JA009725, 2003.

Fairfield, D. H. and Scudder, J. D.: Polar rain: Solar coronal electrons in the Earth's magnetosphere, J. Geophys. Res., 90, 40554068, 1985.

Farrugia, C. J., Sandholt, P. E., Maynard, N. C., Torbert, R. B., and Ober, D. M.: Temporal variations in a four-sheet fieldaligned current system and associated aurorae as observed during a Polar-ground magnetic conjunction in the midmorning sector, J. Geophys. Res., 108(A6), 1230, doi:10.1029/2002JA009619, 2003.

Farrugia, C. J., Lund, E. J., Sandholt, P. E., Wild, J. A., Cowley, S. W. H., Balogh, A., Mouikis, C., Möbius, E., Dunlop, M. W., Bosqued, J.-M., Carlson, C. W., Parks, G. K., Cerisier, J.C., Kelly, J. D., Sauvaud, J.-A., and Rème, H.: Pulsed flows at the high-altitude cusp poleward boundary, and associated ionospheric convection and particle signatures, during a Cluster FAST - SuperDARN-Søndrestrøm conjunction under a southwest IMF, Ann. Geophys., 22, 2891-2905, 2004, http://www.ann-geophys.net/22/2891/2004/.

Frey, H., Immel, T. J., Lu, G., Bonnel, J., Fuselier, S. A., Mende, S. B., Hubert, B., Østgaard, N., and Le, G.: Properties of localized, high-latitude, dayside aurora, J. Geophys. Res., 108(A4),
doi:10.1029/2002JA009332, 2003.

Greenwald, R. A., Baker, K., Dudeney, J. R., Pinnock, M., Thomas, E. C., Villain, J. P., Cerisier, J.-C., Senior, C., Hanuise, C., Hunsucker, R. D., Sofko, G. J., Koehler, J., Nielsen, E., Pellinen, R., Walker, A. D. M., Sato, N., and Yamagishi, H.: DARN/SUPERDARN: A Global View of the Dynamics of HighLatitude Convection, Space Sci. Rev., 71, 761-796, 1995.

Illing, R. M. E. and Hundhausen, A. J.: Observation of a coronal transient from 1.2 to 6 solar radii, J. Geophys. Res., 90, A1, doi:10.1029/JA090iA01p00275, 1985.

Illing, R. M. E. and Hundhausen, A. J.: Disruption of a coronal streamer by an eruptive prominence and coronal mass ejection, J. Geophys. Res., 91, A10, doi:10.1029/JA091iA10p10951, 1986.

Karlsson, T., Marklund, G. T., Figueiredo, S., Johansson, T., and Buchert, S.: Separating spatial and temporal variations in auroral electric and magnetic fields by Cluster multipoint measurements, Ann. Geophys., 22, 2463-2472, 2004, http://www.ann-geophys.net/22/2463/2004/.

Lepping, R. P., Acũna, M. H., Burlaga, L. F., Farrell, W. M., Slavin, J. A., Schatten, K. H., Mariani, F., Ness, N. F., Neubauer, F. M., Whang, Y. C., Byrnes, J. B., Kennon, R. S., Panetta, P. V., Scheifele, J., and Worley, E. M.: The WIND magnetic field investigation, Space Sci. Rev., 71, 207-229, 1995.

Low, B. C.: Coronal mass ejections, magnetic flux ropes, and solar magnetism, J. Geophys. Res., 106, A11, doi:10.1029/2000JA004015, 2001.

Lund, E. J., Farrugia, C. J., and Sandholt, P. E.: Momentum transfer at the high-latitude magnetopause and boundary layers, Ann. Geophys., 26, 2449-2458, 2008, http://www.ann-geophys.net/26/2449/2008/.

Marklund, G., Karlsson, T., and Clemmons, J.: On low-altitude particle acceleration and intense electric fields and their relationship to black aurora, J. Geophys. Res., 102, 17509-17522, 1997.

Marklund, G. T., Ivchenko, N., Karlsson, T., Fazakerley, A., Dunlop, M., Lindqvist, P.-A., Buchert, S., Owen, C., Taylor, M., Vaivalds, A., Carter, P., Andre, M., and Balogh, A.: Temporal evolution of the electric field accelerating electrons away from the auroral ionosphere, Nature, 414, 724-727, 2001.

Meng, C.-I., Akasofu, S.-I., and Anderson, K. A.: Dawn-dusk gradient of the precipitation of low-energy electrons over the polar cap and its relation to the interplanetary magnetic field, J. Geophys. Res., 82, 5271-5275, 1977.

Newell, P. T., Liou, K., and Wilson, G.: Polar cap particle precipitation and aurora: Review and commentary, J. Atmos. Solar-Terr. Phys., 71, 199-215, 2009.

Ogilvie, K. W., Chornay, D., Fritzenreiter, R., Hunsaker, F., Keller, J., Lobell, J., Miller, G., Scudder, J. D., Sittler Jr., E. C., Torbert, R. B., Bodet, D., Needell, G., Lazarus, A. J., Steinberg, J., T., Tappan, J. H., Mavretic, A., and Gergin, E.: SWE, a comprehensive plasma instrument for the WIND spacecraft, Space Sci. Rev., 55, 71-77, 1995.

Øieroset, M., Sandholt, P. E., Luhr, H., Denig, W., and Moretto, T.: Auroral and geomagnetic events at cusp/mantle latitudes in the prenoon sector during positive IMF $B_{y}$ conditions: Signatures of pulsed magnetopause reconnection, J. Geophys. Res., 102, A4, doi:10.1029/96JA03716, 1997.

Provan, G., Yeoman, T. K., and Cowley, S. W. H.: The influence of the IMF $B y$ component on the location of pulsed flows in the dayside ionosphere observed by an HF radar, Geophys. Res. Lett., 
26, 4, doi:10.1029/1999GL900009, 1999.

Provan, G., Milan, S. E., Lester, M., Yeoman, T. K., and Khan, H.: Letter to the Editor: Simultaneous observations of the ionospheric footprint of flux transfer events and dispersed ion signatures, Ann. Geophys., 20, 281-287, 2002,

http://www.ann-geophys.net/20/281/2002/.

Reiff, P. H. and Burch, J. L.: IMF $\mathrm{B}_{\mathrm{y}}$-dependent dayside plasma flow and Birkeland currents in the dayside magnetosphere, 2, A global model for northward and southward IMF, J. Geophys. Res., 90, 1595-1609, 1985.

Reiff, P. H., Burch, J. L., and Heelis, R. A.: Dayside auroral arcs and convection, Geophys. Res. Lett., 5, 391-394, 1978.

Ruohoniemi, J. M. and Greenwald, R. A.: Dependencies of high-latitude plasma convection: Consideration of interplanetary magnetic field, season, and universal time factors in statistical patterns, J. Geophys. Res., 110, A09204, doi:10.1029/2004JA010815, 2005.

Sandholt, P. E. and Farrugia, C. J.: Poleward moving auroral forms (PMAFs) revisited: responses of aurorae, plasma convection and Birkeland currents in the pre- and postnoon sectors under positive and negative IMF By conditions, Ann. Geophys., 25, 16291652, 2007a,

http://www.ann-geophys.net/25/1629/2007/.

Sandholt, P. E. and Farrugia, C. J.: The role of poleward moving auroral forms in the dawn-dusk precipitation asymmetries induced by IMF $B_{y}$, J. Geophys. Res., 112, A04203, doi:10.1029/2006JA011952, 2007b.

Sandholt, P. E. and Farrugia, C. J.: Plasma flow channels at the dawn/dusk polar cap boundaries: momentum transfer on old open field lines and the roles of IMF $B_{\mathrm{y}}$ and conductivity gradients, Ann. Geophys., 27, 1527-1554, 2009, http://www.ann-geophys.net/27/1527/2009/.

Sandholt, P. E., Farrugia, C. J., and Denig, W. F.: Detailed dayside auroral morphology as a function of local time for southeast IMF orientation: implications for solar wind-magnetosphere coupling, Ann. Geophys., 22, 3537-3560, 2004, http://www.ann-geophys.net/22/3537/2004/.

Sandholt, P. E., Dyrland, M., and Farrugia, C. J.: Dayside aurorae and polar arcs under south-east IMF orientation, Ann. Geophys., 24, 3421-3432, 2006, http://www.ann-geophys.net/24/3421/2006/.

Sibeck, D. and Lin, R.-Q.: Concerning the motion of flux transfer events generated by component reconnection across the dayside magnetopause, J. Geophys. Res., 115, A04209, doi:10.1029/2009JA014677, 2010.
Siscoe, G. L. and Siebert, K. D.: Local boundary layer properties from non-local processes illustrated by MHD simulations, in: Earth's Low-Latitude Boundary Layer, edited by: Newell, P. T. and Onsager, T., no. 133 in AGU Monograph, pp. 377-384, American Geophysical Union, Washington, D.C., 2003.

Sonnerup, B. U. O. and Siebert, K. D.: Theory of the low-latitude boundary layer and its coupling to the ionosphere: A tutorial review, in: Earth's Low-Latitude Boundary Layer, edited by: Newell, P. T. and Onsager, T., vol. 133 of Geophysical Monograph, pp. 13-32, American Geophysical Union, Washington, D.C., 2003.

Sotirelis, T., Newell, P. T., and Meng, C.-I.: Polar rain as a diagnostic of recent rapid dayside merging, J. Geophys. Res., 102, A4, doi:10.1029/96JA03564, 1997.

Stern, D. P.: Magnetospheric dynamo processes, in: Magnetospheric Currents, edited by: Potemra, T. A., vol. 28 of Geophys. Monogr., pp. 200-207, AGU, Washington, D.C., 1984.

Svalgaard, L.: Polar cap magnetic variations and their relationship with the interplanetary magnetic sector structure, J. Geophys. Res., 78, 2064-2078, 1973.

Thorolfsson, A., Cerisier, J.-C., Lockwood, M., Sandholt, P. E., Senior, C., and Lester, M.: Simultaneous optical and radar signatures of poleward-moving auroral forms, Ann. Geophys., 18, 1054-1066, 2000, http://www.ann-geophys.net/18/1054/2000/.

Tsurutani, B., McPherron, R., Gonzalez, W., Lu, G., Sobral, J. H. A., and Gopalswamy, N. (Eds.): Recurrent Magnetic Storms: Corotating Solar Wind Streams, vol. 167 of Geophysical Monograph, AGU, Washington, D.C., 2006.

Wild, J. A., Milan, S. E., Cowley, S. W. H., Dunlop, M. W., Owen, C. J., Bosqued, J. M., Taylor, M. G. G. T., Davies, J. A., Lester, M., Sato, N., Yukimatu, A. S., Fazakerley, A. N., Balogh, A., and Rème, H.: Coordinated interhemispheric SuperDARN radar observations of the ionospheric response to flux transfer events observed by the Cluster spacecraft at the high-latitude magnetopause, Ann. Geophys., 21, 1807-1826, 2003, http://www.ann-geophys.net/21/1807/2003/. 